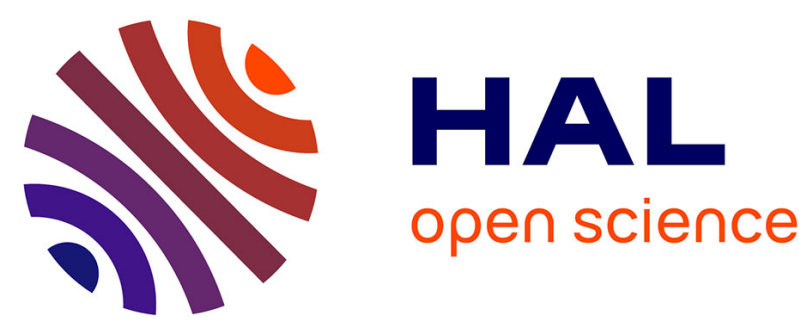

\title{
Modeling the variability in annual carbon fluxes related to biological soil crusts in a Mediterranean shrubland
}

B. Wilske, J. Burgheimer, K. Maseyk, A. Karnieli, E. Zaady, Mo Andreae, D. Yakir, J. Kesselmeier

\section{- To cite this version:}

B. Wilske, J. Burgheimer, K. Maseyk, A. Karnieli, E. Zaady, et al.. Modeling the variability in annual carbon fluxes related to biological soil crusts in a Mediterranean shrubland. Biogeosciences, 2009, 6, pp.7295-7324. bioemco-00455957

\section{HAL Id: bioemco-00455957 https://hal-bioemco.ccsd.cnrs.fr/bioemco-00455957}

Submitted on 30 May 2020

HAL is a multi-disciplinary open access archive for the deposit and dissemination of scientific research documents, whether they are published or not. The documents may come from teaching and research institutions in France or abroad, or from public or private research centers.
L'archive ouverte pluridisciplinaire HAL, est destinée au dépôt et à la diffusion de documents scientifiques de niveau recherche, publiés ou non, émanant des établissements d'enseignement et de recherche français ou étrangers, des laboratoires publics ou privés.

\section{(c)(1)}

Distributed under a Creative Commons Attribution| 4.0 International License 
Biogeosciences Discuss., 6, 7295-7324, 2009

www.biogeosciences-discuss.net/6/7295/2009/

(C) Author(s) 2009. This work is distributed under

\section{Modeling the variability in annual carbon fluxes related to biological soil crusts in a Mediterranean shrubland}

B. Wilske ${ }^{1,2}$, J. Burgheimer ${ }^{3}$, K. Maseyk ${ }^{1}$, A. Karnieli ${ }^{3}$, E. Zaady ${ }^{4,{ }^{*}}$, M. O. Andreae ${ }^{2}$, D. Yakir $^{1}$, and J. Kesselmeier ${ }^{2}$

${ }^{1}$ Department Environmental Science and Energy Research, Weizmann Institute of Sciences, Rehovot 76100, Israel

${ }^{2}$ Max Planck Institute for Chemistry, Biogeochemistry Department, P.O. Box 3060, 55020, Mainz, Germany

${ }^{3}$ The Remote Sensing Laboratory, Jacob Blaustein Institutes for Desert Research, Ben-Gurion University of the Negev, Sede Boker Campus, 84990, Israel

${ }^{4}$ The Desertification and Restoration Ecology Research Center, Jacob Blaustein Institutes for Desert Research, Ben-Gurion University of the Negev, Sede Boker Campus, 84990, Israel "now at: Department of Natural Resources, Agriculture Research Organization,

Gilat Research Center, Ministry of Agriculture, Mobil Post Negev 85280, Israel

Received: 10 July 2009 - Accepted: 15 July 2009 - Published: 23 July 2009

Correspondence to: B. Wilske (brkwils@yahoo.com)

Published by Copernicus Publications on behalf of the European Geosciences Union.
Modeling the variability in annual carbon fluxes related to BSC

B. Wilske et al.

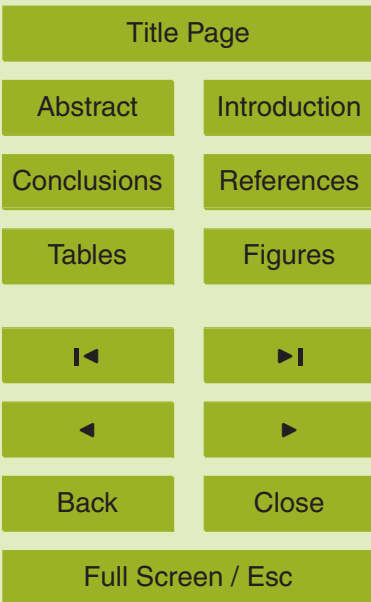

Printer-friendly Version

Interactive Discussion 


\section{Abstract}

Biological soil crusts (BSC) constitute a spatially prominent part of the photosynthesizing vegetation in many dryland ecosystems. This study assesses the annual net carbon deposition related to BSC growth in a Mediterranean shrubland for the years

5 2001-2003 using a model developed to account for the nature of hydration in the poikilohydric life trait of the BSC. Data for BSC-related net $\mathrm{CO}_{2}$ fluxes were obtained from in-situ measurements at the International Long-term Ecological Research site Sayeret Shaked (ILTER-SSK) in the northern Negev Desert, Israel. The BSC was smooth to rugose, up to $15 \mathrm{~mm}$ thick and consisted mainly of mosses, cyanobacteria and cyanolichens. In order to obtain annual estimates, BSC-related $\mathrm{CO}_{2}$ fluxes were correlated with climate records provided by the meteorological station of the Terrestrial Ecosystem Monitoring Site network (TEMS) adjacent to SSK. The annual carbon deposition related to BSC growth was assessed from (1) an overall mean of net $\mathrm{CO}_{2}$ flux multiplied with annual activity periods of BSC based on precipitation records, and (2) from 15 a simple precipitation-driven activity model (PdAM).

This model combines an algorithm, previously developed to model gas exchange processes in vascular plants, with an empirical module that switches the algorithm on as soon as water is available to maintain activity of poikilohydric BSC. Based on a constant BSC area index of $0.6 \mathrm{~m}^{2} \mathrm{~m}^{-2}$ at ILTER-SSK, the final model suggests a 20 large inter-annual variability in BSC-related net carbon deposition ranging from 7 to $51 \mathrm{~kg} \mathrm{ha}^{-1} \mathrm{yr}^{-1}$.

\section{Introduction}

Recent studies have detected large annual $\mathrm{CO}_{2}$ deposition fluxes in desert ecosystems in the USA and China (Wohlfahrt et al., 2008; Xie et al., 2008), although dryland ecosystems have usually been regarded as being carbon neutral at best (Stone, 2008). Semiarid and arid ecosystems together encompass about $30 \%$ of the Earth's land sur-
BGD

$6,7295-7324,2009$

\section{Modeling the variability in annual carbon fluxes related to BSC}

B. Wilske et al.

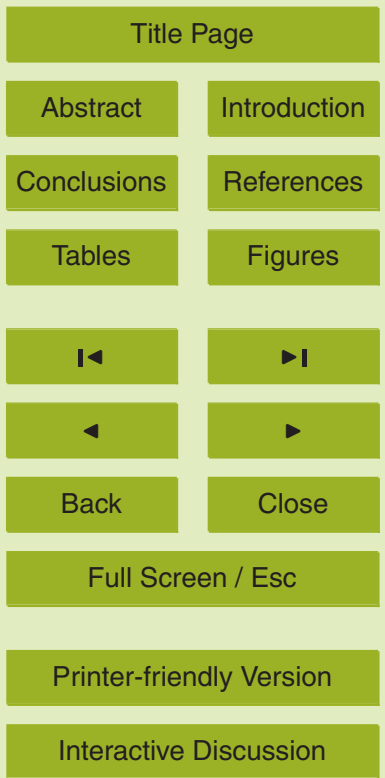


face (UNEP, 1997; Wohlfahrt et al., 2008) and represent a potentially significant carbon sink, if similar deposition rates were to be widespread. Vegetation is the largest terrestrial sink for $\mathrm{CO}_{2}$ and provides the major input for the global soil carbon stock, which is about three times larger than the carbon stored in the vegetation itself (IPCC, 2001). 5 Sparsely vegetated deserts and semi-deserts contribute only about $0.7 \%$ of the terrestrial biomass (Whittaker and Likens, 1975), whereas about $90 \%$ is stored in forests ecosystems (Dolman et al., 2003). Hence, most research efforts focus on the boreal, temperate, and tropical biomes, where the carbon stocks in the soil and/or the vegetation are very large. Yet, estimates of land-atmosphere $\mathrm{CO}_{2}$ fluxes are still highly 10 uncertain, which may be due to the low precision of both the estimates of larger as well as of minor sinks (Kesselmeier et al., 2002). Inter-annual variability in natural carbon sequestration may add to the overall uncertainty. Similarly, the recently reported carbon deposition in deserts included high uncertainties (Wohlfahrt et al., 2008; Xie et al., 2008). Three possible sink functions were discussed as being responsible for the 15 ecosystem-scale $\mathrm{CO}_{2}$ uptake: (1) increased carbon sequestration by vascular vegetation due to increased precipitation in recent years, (2) chemical uptake by alkaline desert soils, and (3) carbon sequestration by BSC.

Several previous studies have considered BSC as a potentially important carbon sink in sparsely vegetated semiarid and arid areas (e.g., Beymar and Klopatek, 1991;

Elbert et al., 2009; Lange et al., 1992; Evans and Johansen, 1999; Zaady et al., 2000). Where water supply is erratic or rainfall is restricted to a short season, BSC complement the sparse ground cover of vascular vegetation. With a surface cover of up to $70 \%$ (Belnap et al., 2001), they represent a spatially prominent part of the photosynthesizing vegetation in dryland ecosystems (Burgheimer et al., 2006a; Karnieli and Tsoar, 25 1995; Karnieli et al., 1996, 2001). BSC include mosses, lichens, algae, cyanobacteria, microfungi and bacteria in various proportions (Lange et al., 1992; West, 1990). These organisms are subjected to perpetual cycles of hydration and desiccation, resulting in activity and anabiosis (i.e., poikilohdric dormancy), respectively (Belnap et al., 2001). BSC have many important functions in dryland ecosystem (reviewed in
BGD

$6,7295-7324,2009$

\section{Modeling the variability in annual carbon fluxes related to BSC}

B. Wilske et al.

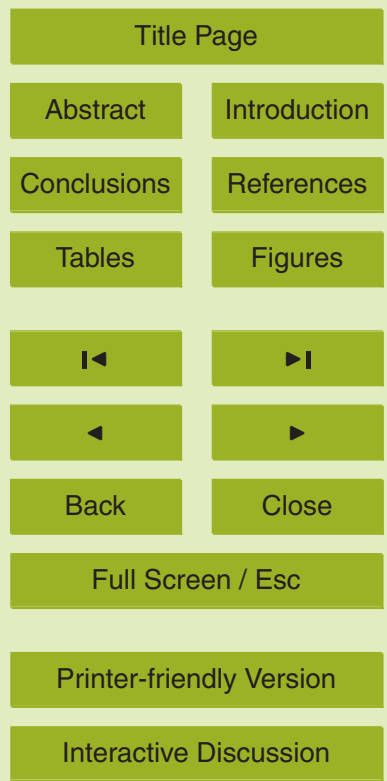


Belnap and Lange, 2001). For example, BSC stabilize and seal soil surfaces (Belnap and Gillette, 1997), increase soil organic matter content (Guo et al., 2008), reduce soil erosion and dust injection into the atmosphere (Lazaro et al., 2008), and decrease soil water evaporation (Belnap, 2006; Zhang et al., 2008). Cyanobacterial components in 5 BSC increase the ecosystem N-availability (e.g., Housman et al., 2006; but see also Zaady et al., 1998). Photosynthetic net $\mathrm{CO}_{2}$ assimilation of $\mathrm{BSC}$ can recover on very small amounts of precipitation within $20 \mathrm{~min}$ and reach maximum rates in a couple of hours (Lange, 2001). Maximum rates of net $\mathrm{CO}_{2}$ assimilation of soil crust lichens were reportedly in the same order of magnitude as those of concomitant vascular plants or 10 plants of temperate regions (Lange, 2001; Lange et al., 1990, 1970). Precipitation frequency has a strong control on BSC-related carbon fluxes (Housman et al., 2006; Wilske et al., 2008), but BSC yield significant $\mathrm{CO}_{2}$ assimilation with relatively small moisture supplies such as from dew and fog (Jeffries et al., 1993a, b; Kappen et. al., 1980; Kidron et al., 2002; Lange et al., 1998; Palmer and Friedmann, 1990; Veste et 15 al., 2001).

Some studies have assessed the role of BSC in ecosystem carbon dynamics (Evans and Lange, 2001; Lange, 2000, 2001; Lange et al., 1994). Assessments of carbon exchange may be relatively reliable if the predominant water supply allows a correlation with distinct time windows of activity, e.g., in cases where BSC growth depends exclusively on fog events (Lange et al., 1994). In contrast, in most of the semiarid and arid areas, the moisture supply is composed of different sources, and unless BSC can be monitored with automated systems (Lange, 2000; Lange et al., 1997), their discontinuous activity represents the major obstacle to assess BSC-related carbon deposition. To overcome this problem, we modelled BSC activity including photosynthesis and respiration by means of continuous climate records and discontinuous data on BSC-related $\mathrm{CO}_{2}$ fluxes obtained from field measurements. We present a model, in which moisture records of precipitation (PPT), soil volumetric water content (VWC) and relative air humidity $(\mathrm{RH})$ trigger a common algorithm to modulate the BSC-related net carbon fluxes.

BGD

$6,7295-7324,2009$

\section{Modeling the variability in annual carbon fluxes related to BSC}

B. Wilske et al.

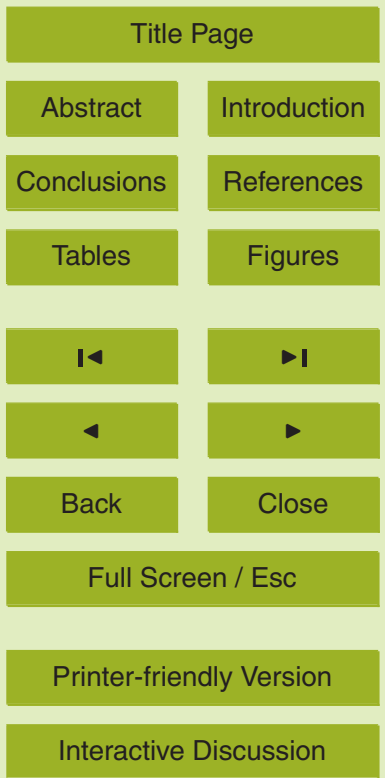




\section{Materials and methods}

\subsection{Study site}

BGD

BSC-related $\mathrm{CO}_{2}$ fluxes were investigated at ILTER-SSK near Beer-Sheva in the northern Negev Desert, Israel (31 $17^{\prime}$ N $34^{\circ} 37^{\prime}$ E; Gosz et al., 2000; http://Iter.bgu.ac.il/sites/ 5 ssd.aspx). Located on the $200 \mathrm{~mm}$ isohyet, the area is representative for the transition from the semiarid to the arid desert in Israel (Zaady et al., 2000). ILTER-SSK is a hilly area (160-190 m a.s.l.) of Eocene chalk bedrock covered by loess soil with sandy loam texture (TEMS classification: Serozem; US classification: Calcixerollic, Xerochrepts). Grasses such as Stipa capensis Thunb. dominate for a short period at the end of the wet season (February to April). For about two thirds of the year the vegetation at ILTER-SSK is dominated by scattered patches of shrubs (e.g., Noaea mucronata (Forssk.) Asch. \& Schweinf., Atractylis serratuloides Cass., Thymelea hirsuta L.) (Zaady et al., 2000), which are embedded in a matrix of soil-dwelling BSC (Boeken et al., 2004).

\subsection{BSC type}

The species compositions contributing to BSC in Israel's Negev Desert was compiled by Friedmann and Galun (1974) and Lange et al. (1992). According to the classification by Rosentreter et al. (2007), the soil-dwelling BSC at ILTER-SSK varied between the smooth and rugose type. On north-facing slopes, BSC were up to $15 \mathrm{~mm}$ thick and consisted of mosses (dominated by Crossidium crassinerve De Not.), cyanobacteria (Nostoc punctiforme L., Microcoleus vaginatus (Vauch.) Gomont), dark crustose cyanolichens (Collema spec.), and algae (Zaady et al., 1998, 2000; Wilske et al., 2008). On south-facing slopes, BSC were up to $10 \mathrm{~mm}$ thick and dominated by cyanobacterial crusts and scattered mosses (mainly Aloina bifrons De Not.) (Zaady et al., 2000). Contributions of the three main components (mosses, cyanobacteria and cyano-lichens) alternated on the large scale and on the micro scale following micro topography and

6, 7295-7324, 2009

\section{Modeling the variability in annual carbon fluxes related to BSC \\ B. Wilske et al.}

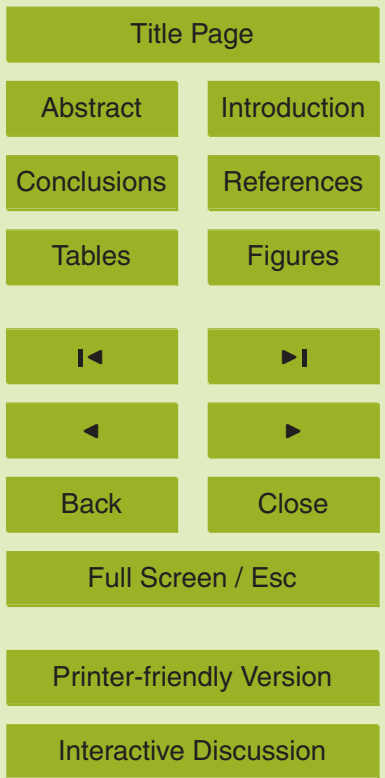


microclimate. The sample plots for measurements of BSC-related $\mathrm{CO}_{2}$ fluxes were situated on a slightly NNE declining slope. To represent the ecosystem contributions, the sample plots enclosed mixed BSC comprising cyanobacteria, lichens, and mosses in 1:1:1 proportion (Wilske et al., 2008). At the time of the measurements, the overall 5 BSC area index at ILTER-SSK was $0.6 \mathrm{~m}^{2} \mathrm{~m}^{-2}$, thereby reflecting the uncovered BSC surfaces during the months without presence of annual plants such as in October 2002 (Burgheimer et al., 2006a).

\section{$2.3 \mathrm{CO}_{2}$ flux and climate records}

In situ measurements of the BSC-related net $\mathrm{CO}_{2}$ fluxes were conducted during 23 10 3-day field campaigns within the periods November 2001-May 2002 and September 2002-May 2003.

BSC-related $\mathrm{CO}_{2}$ fluxes were investigated using permanent soilborne collars and a mobile twin set of Teflon bag equipped enclosures. Enclosures were rotated between three to four sample- and two reference plots. The collars enclosed either $160 \mathrm{~cm}^{2}$ of 15 native BSC or bare soil. Enclosures were flushed with $1 \mathrm{~L} \mathrm{~min}^{-1}$ of ambient air. BSCrelated $\mathrm{CO}_{2}$ fluxes were obtained with an infrared gas analyser (IRGA, LI-7000, LICOR, Lincoln, USA) in differential mode and by measuring a BSC sample versus a soil sample. To check the differential measurements, individual BSC and soil samples were intermittently measured versus a blank cuvette. In this study, negative fluxes represent 20 net $\mathrm{CO}_{2}$ deposition due to $\mathrm{CO}_{2}$ uptake by $\mathrm{BSC}$ photosynthesis, and positive fluxes represent net emission due to $\mathrm{BSC}$ respiration. The general enclosure time of samples was $15 \mathrm{~min} . \mathrm{CO}_{2}$ raw data were corrected for drifts due to IRGA temperature and water content of sample air by using linear regressions from blank cuvette records. Data with high uncertainty due to excessive variance of blank values were eliminated. The data 25 that we used to model BSC-related $\mathrm{CO}_{2}$ fluxes were based on 10-min blank averages with standard deviations $<0.01 \mu \mathrm{mol} \mathrm{m} \mathrm{m}^{-2} \mathrm{~s}^{-1}$ and a resolution of $0.05 \mu \mathrm{mol} \mathrm{m}^{-2} \mathrm{~s}^{-1}$.

Microclimate parameters at the sample plots were recorded simultaneously with the $\mathrm{CO}_{2}$ flux measurements. Standard probes close to the sample plots recorded the fol-
BGD

6, 7295-7324, 2009

\section{Modeling the variability in annual carbon fluxes related to BSC}

B. Wilske et al.

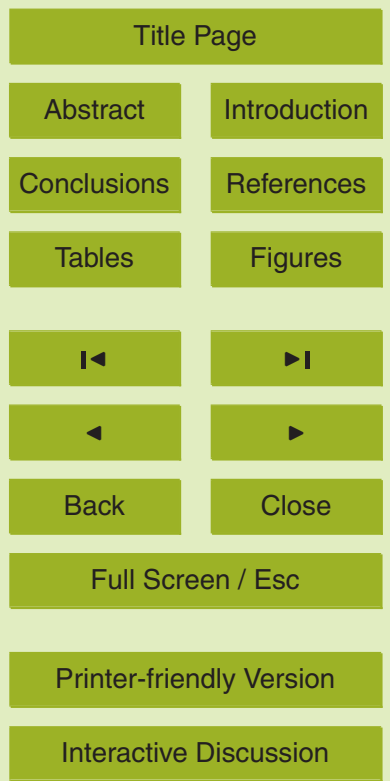


lowing microclimate conditions in one-minute intervals: Photosynthetic active radiation (PAR, $\mu \mathrm{mol} \mathrm{m}^{-2} \mathrm{~s}^{-1}$; LI-190SZ, LICOR, USA), short wave radiation $\left(\mathrm{Wm}^{-2}\right.$; CM11, Kipp \& Zonen, NL), incidence of PPT (two Wetness Sensing Grids, Campbell, UK), air temperature $\left(T_{a},{ }^{\circ} \mathrm{C}\right)$ and $\mathrm{RH}(\%)$ at $0.2 \mathrm{~m}$ (Handylog 503-2MB, Driesen\&Kern, FRG) 5 and $0.5 \mathrm{~m}$ above soil surface (Rotronic, Walz, FRG), soil surface temperature $\left(T_{\mathrm{SS}},{ }^{\circ} \mathrm{C}\right.$ ) and $T_{a} 10 \mathrm{~mm}$ above soil surface (covered Type E thermo-couples, Campbell, UK). VWC of the soil at the plots was determined gravimetrically. Details on the measurements and the activity pattern that drive BSC-related $\mathrm{CO}_{2}$ fluxes have been presented in a previous paper for the first of the two periods (Wilske et al., 2008).

10 Continuous climate records were obtained from the automated TEMS station at ILTER-SSK for the years 2000-2003 (TEMS-SSK, http://www.fao.org/gtos/tems/tsite show.jsp?TSITE_ID =1609). TEMS-SSK is located at a distance of $300 \mathrm{~m}$ from the sample plots and provided site relevant climate data at a 15-min time resolution. Climate data from TEMS-SSK used to model BSC activity included PPT $(\mathrm{mm}), \mathrm{RH}(\%), T_{a}\left({ }^{\circ} \mathrm{C}\right)$, 15 soil temperature at $5 \mathrm{~cm}$ depth $\left(T_{S} 5,{ }^{\circ} \mathrm{C}\right)$, solar insulation $\left(R_{\text {in }}, \mathrm{W} \mathrm{m}^{-2}\right)$, VWC of the

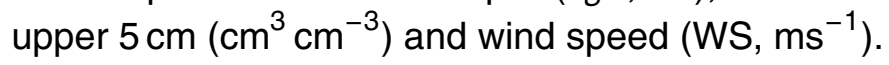

\section{Assessments of BSC-related carbon deposition}

Atmospheric water supply represents the main driver of $\mathrm{BSC}$-related $\mathrm{CO}_{2}$ fluxes as it activates BSC from anabiosis (i.e., poikilohydric dormancy), whereafter photosynthesis and respiration are maintained until desiccation. We correlated BSC-related net $\mathrm{CO}_{2}$ fluxes from ILTER-SSK with climate records of the adjunct TEMS station to assess the annual carbon deposition from dry to dry season (1 June 200i-30 May 200i+1). PPT records from TEMS-SSK provided the main basis for two types of assessments on BSC activity and related annual net carbon deposition. Carbon deposition was (1) extrapolated from estimated activity periods and mean net exchange rates, and (2) simulated using a precipitation-driven activity model (PdAM).

BGD

$6,7295-7324,2009$

\section{Modeling the variability in annual carbon fluxes related to BSC \\ B. Wilske et al.}

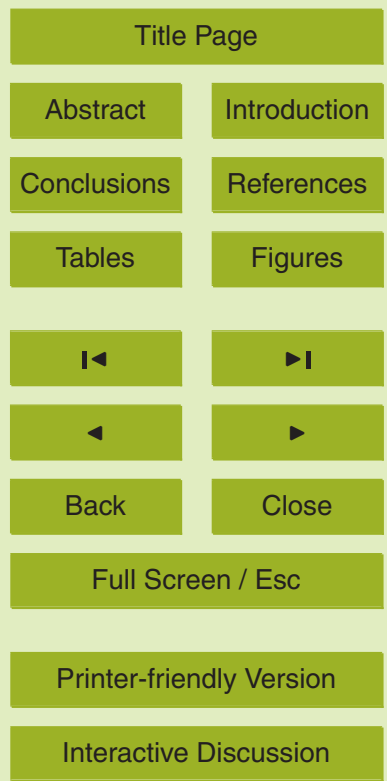




\subsection{The extrapolation of mean exchange rates}

BSC activity was observed in situ with various types of moisture supply such as rain, fog, dew, and condensation from water previously stored in the upper layers of the soil. The field-observations of water availability and periods of BSC-related $\mathrm{CO}_{2}$ flux 5 in 2001-2002 suggested that the bulk carbon deposition by the soil-dwelling BSC in the semiarid grass-shrubland occurred during activity periods that were supplied by rain (Wilske et al., 2008). Based on this result, we screened the 15-min records of BSC-related net $\mathrm{CO}_{2}$ flux to obtain means of daytime net $\mathrm{CO}_{2}$ deposition and night respiratory $\mathrm{CO}_{2}$ emission. The annual BSC-related net carbon deposition was then calculated by extrapolating mean fluxes using PPT records of the period of 1 June 2001-30 May 2002. The $\mathrm{CO}_{2}$ emission from respiration ranged between 0.05$0.1 \mu \mathrm{mol} \mathrm{m}{ }^{-2} \mathrm{~s}^{-1}$ during most of the nights with BSC activity, and we used a mean value of $0.075 \mu \mathrm{mol} \mathrm{m} \mathrm{m}^{-2} \mathrm{~s}^{-1}$ for the calculation. The mean net $\mathrm{CO}_{2}$ assimilation rate of active BSC during daylight hours was $0.4 \mu \mathrm{mol} \mathrm{m}^{-2} \mathrm{~s}^{-1}$. We compiled periods of 15 measured activity, ad hoc comments to field data, and the 15-min precipitation records of the TEMS station in order to determine an approximate relationship between certain amounts of PPT and the resulting length of activity periods. It was obvious that the categories of PPT and activity periods represented a trade off between different conditions that affect the desiccation of BSC (Table 1). For example, based on the field observations, $0.5 \mathrm{~mm}$ PPT could maintain respiration in BSC for almost whole nights and still allow some photosynthesis during early morning hours. The same amount would evaporate within one hour under strong midday sunlight conditions. However, PPT that accumulated up to $0.5 \mathrm{~mm}$ mostly coincided with cloudy weather, which justified extending the general activity period to three hours.

Based on the categories shown in Table 1, the annual PPT of $150.8 \mathrm{~mm}$ was weighted to $992 \mathrm{~h}$ of BSC activity including $617 \mathrm{~h}$ of night activity and $375 \mathrm{~h}$ of daylight activity within the 2001-2002 target period. The extrapolation of the mean exchange rates resulted in $3.9 \mathrm{~g} \mathrm{C} \mathrm{m}^{-2} \mathrm{yr}^{-1}, 1.2 \mathrm{gC} \mathrm{m}^{-2} \mathrm{yr}^{-1}$, and $2.7 \mathrm{~g} \mathrm{C} \mathrm{m}^{-2} \mathrm{yr}^{-1}$ (or
BGD

$6,7295-7324,2009$

\section{Modeling the variability in annual carbon fluxes related to BSC \\ B. Wilske et al.}

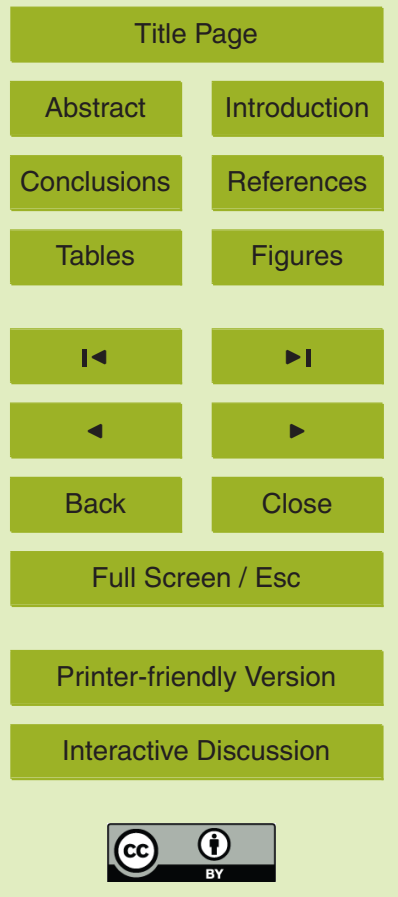


$27 \mathrm{~kg} \mathrm{Cha}^{-2} \mathrm{yr}^{-1}$ in Table 4) for the annual total of the daytime net ecosystem assimilation, the night respiratory emission, and the net ecosystem carbon deposition by BSC at ILTER-SSK, respectively.

\section{BGD}

$6,7295-7324,2009$

\subsection{The PdAM simulation}

5 BSC-related net $\mathrm{CO}_{2}$ fluxes were used to fit the model to the most diverse climate conditions and in particular to reflect important periods having high, moderate and low moisture conditions. Data from 10 field campaigns were used to develop and optimise the agreement between the modelled and the observed BSC-related $\mathrm{CO}_{2}$ fluxes (Table 2). Data from the other 13 field campaigns contained no new information and had only low fluxes with almost no variation to test the simulation.

Similar to the previous calculation (see 3.1), PdAM employs climate data from TEMSSSK and the approximation between PPT and periods of BSC activity (Table 1). In PdAM, the same data were used to simulate the in-situ measured diurnal courses of BSC activity. PdAM was based on an algorithm for gas exchange in homoiohydric 15 (vascular) vegetation supplemented by two modules that de-/activate and trigger gas exchange processes in poikilohydric (non-vascular) vegetation. The three main modules of PdAM are (1) the activation switch, or simply switch, (2) the trigger, and (3) the modulation, i.e., the algorithm. To demonstrate the effects of various parameters on the assessments, we present results from three model versions PdAM-r, -r-sm and $-r-$ sm-rh, where $r$, sm and rh stand for PPT, high soil moisture (i.e., VWC $>0.22 \mathrm{~cm}^{3} \mathrm{~cm}^{-3}$ of the upper $5 \mathrm{~cm}$ ), and relative air humidity $>83.2 \%$, respectively (Table 4 ).

\subsubsection{The activation switch}

PPT records were used as a main switch to drive BSC activity in accordance with the PPT-BSC activity relationship shown in Table 1. In PdAM-r, only PPT records were 25 used to activate BSC. High sm and high rh were introduced during model development (i.e., model versions PdAM-r-sm and -r-sm-rh), because PPT records alone failed to

\section{Modeling the variability in annual carbon fluxes related to BSC \\ B. Wilske et al.}

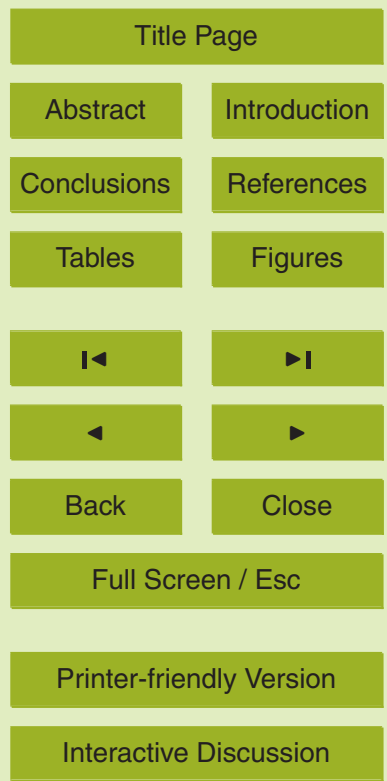


activate BSC for some significant periods where activity was observed. The high rhmotif was introduced to substitute for missing records of condensed moisture supply from fog or dew. The thresholds for the activation of BSC from high sm and high rh were derived from days with activity but without rain. In both cases the lowest gates for 5 both parameters were set as tight as possible to maintain the monitored BSC activity exactly.

\subsubsection{The trigger}

To achieve increased BSC-related $\mathrm{CO}_{2}$ fluxes as observed with longer periods of BSC activity, the switch signals listed in Table 1 can accumulate. The trigger section of PdAM translates the accumulated switch signals to different levels of activation (Table 3 ). The accumulated values of switches in PdAM-r+sm + rh correspond to three levels of activation: 1,7 , and 8 to a level of $0.5 ; 2,3,4$ and 5 to a level of 1 ; and 6 to a level of 0.75 . For example: PPT of $0.1 \mathrm{~mm}$ drives activity for two hours, but only triggers level 1 with increased $\mathrm{RH}$, otherwise level 0.5 is triggered. Conversely, time windows of PPT incidences can overlap and accumulate to values of 7 or 8 , which also trigger the level 0.5 in order to simulate water supra-saturation. The trigger level 0.75 on 6 smoothened the transition between the 0.5- and the 1-level.

The above constellation of triggers could not simulate some observed courses of rapid desiccation. Irradiance was checked for its ability to promote rapid desiccation but high gates to instantaneous as well as accumulated irradiance were from case to case as effective as counterproductive. Instead, a dry-out-motif was extracted from a day with high photosynthesis rates until midday and rapid desiccation following good moisture conditions. The additional control consisted of a two hour average of WS $>4.9 \mathrm{~ms}^{-1}$ and PPT $<0.4 \mathrm{~mm}$ within the last $8 \mathrm{~h}$. The same motif was superimposed to 25 the accumulated moisture trigger reducing it by $50 \%$, from $1,0.75$ and 0.5 to $0.5,0.375$ and 0.25 , respectively.

BGD

$6,7295-7324,2009$

\section{Modeling the variability in annual carbon fluxes related to BSC}

B. Wilske et al.

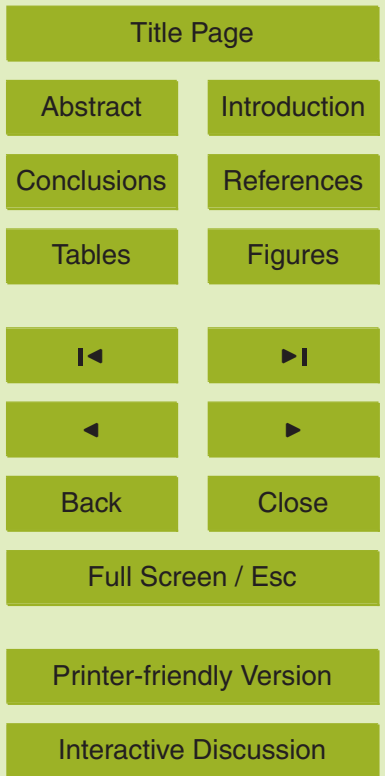




\subsubsection{The modulation}

The activation levels trigger an algorithm to modulate $\mathrm{BSC}$-related $\mathrm{CO}_{2}$ fluxes over certain periods of time. PdAM uses an existing algorithm as framework to modulate photosynthesis and respiration of BSC with light and temperature. The algorithm is

5 based on a description of reaction kinetics for poikilotherm development (Sharpe and DeMichele, 1977) and was further developed to model the light and temperature dependence of volatile organic compounds (Guenther et al., 1993, 1997; Schuh et al., 1997). We modified the algorithm to simulate the BSC-related $\mathrm{CO}_{2}$ emission and deposition fluxes. Hence, the terms and constants for emission from pools and light dependent emission were changed to model respiration and net photosynthesis in activated BSC, respectively (see the algorithm in Appendix A).

Data input to either of the modules was derived from TEMS-SSK, which is a standard meteorological station and the climate sensors and sensor positions were not established to monitor microclimatic conditions that are relevant for BSC growth. For exam15 ple, diurnal courses of BSC-affecting soil surface temperature $\left(T_{S S B}\right)$ typically follow the course of air temperature with some delay. Various parameters and parameter combinations were tested to facilitate use of light and temperature data from TEMS-SSK as input for the algorithm. As photosynthetic active radiation (PAR) was not available, we used 15-min mean solar insulation $\left(\mathrm{W} \mathrm{m}^{-2}\right)$ as the light parameter, and a construct of BSC-affecting temperature $\left(T_{\mathrm{SSB}}\right)$. $T_{\mathrm{SSB}}$ was constructed from TEMS-SSK air temperature $\left(T_{a},{ }^{\circ} \mathrm{C}\right)$, and soil temperature at $5 \mathrm{~cm}$ depth $\left(T_{s} 5,{ }^{\circ} \mathrm{C}\right)$ to simulate the $T_{\mathrm{SS}}$, which was recorded at the sample plots during field measurements. The constructed temperature $T_{\mathrm{SSB}}=\left(\left(T_{s} 5-7\right)+\left(T_{a}-3\right)\right)$ matched well with the measured morning increases of $T_{\text {SS }}$ and it simulated the larger amplitude of soil surface temperature during the dayrange. Yet, $T_{\mathrm{SSB}}$ was used on the assumption there would be no BSC activity to be affected during those times.

\section{Modeling the variability in annual carbon fluxes related to BSC \\ B. Wilske et al.}

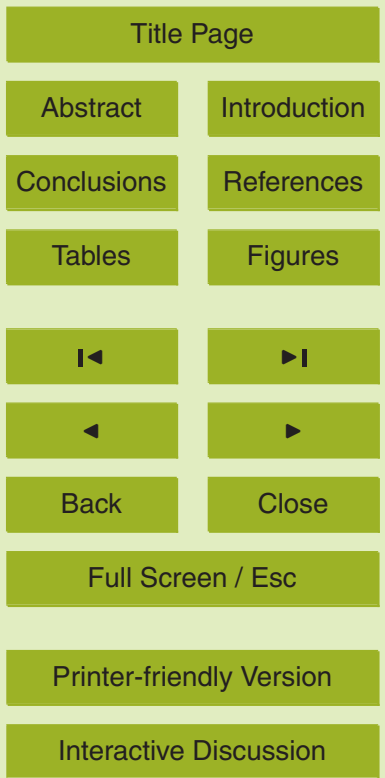




\subsection{Model performance}

The activation switch performed fairly well to start the algorithm when moisture from the different sources was available (Fig. 1a-k). Model courses of photosynthesis/respiration matched experimental data very well, if recurring precipitation provided 5 good moisture supply to BSC (Fig. 1c (8/01/02), e (20-21/01/02), f (25/11/02), g (11/12/02), h (20-21/01/03), and i (22/02/03)). Alternating trigger levels created some stepwise changes in fluxes (e.g., Fig. 1f, 25 November 2002). The sm-motif simulated well the extended activity periods following accumulated water supply and subsequently cloudy weather with lower light conditions. The sm-motif, partly in connection with the rh-motif, kept BSC active for the whole days of 14 January and 12 December 2002 (Fig. 1d, g; light conditions not shown). To switch activity for the morning of the 15 January 2002 would have required an extension of the period set for the influence of increased soil moisture (Fig. 1b). However, an increase of the period would have also required more mechanisms for down regulation, which were not available.

The rh-motif successfully activated important periods with night respiration (e.g., Fig. 1d), early morning assimilation (Fig. 1k) and substituted precipitation supplied by fog (Fig. 1e, 20/01/2002 about 03:00-09:00 h). The sum of all over- and underestimates of night respiration was $-0.09 \mu \mathrm{mol} \mathrm{m}^{-2} \mathrm{~s}^{-1}$, thus showing a reasonable cross compensation. The rh-motif also switched the algorithm to night respiration during the dry season (May-September). These $\mathrm{RH}$-triggered emissions accounted for $51 \%$ and $44 \%$ of the total emission fluxes in 2001-2002 and 2002-2003, respectively. Higher wind speeds occurred quite frequently and the motif for rapid desiccation was effective $17 \%$ and $21 \%$ of the years $2001-2002$ and $2002-2003$.

The data set of each year included one incident indicating a short but intense socalled resaturation burst. The model could not reproduce such events, and these days were not included in the evaluation of the model, because the affecting PPT was not recorded by TEMS-SSK.

A main mismatch occurred on the 22 November 2001. Moisture supply was sufficient
BGD

$6,7295-7324,2009$

\section{Modeling the variability in annual carbon fluxes related to BSC \\ B. Wilske et al.}

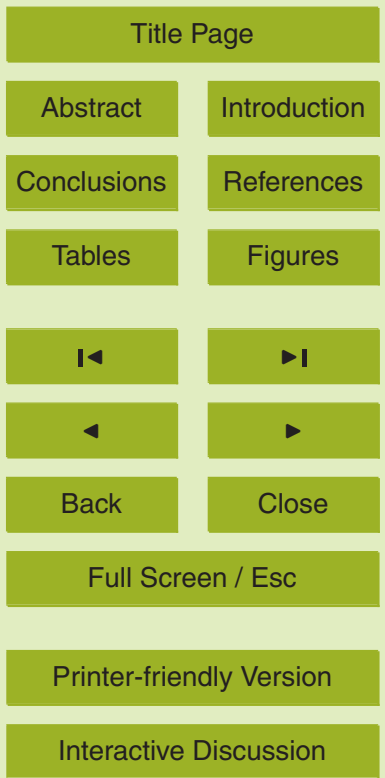


but experimental data showed a notably low activity, which could not be satisfied by any universal trigger or algorithm. The same day contributed a number of high model values versus low measured values (Fig. 2, along the y-axis of the correlation chart).

The model fit was checked with respect to the settings of the activation switch, the 5 balance of the trigger, and the BSC constants, by plotting the correlation between experimental and model data. For every change of settings, we checked the correlation for the years 2001-2002 and 2002-2003 independently. The final settings were determined by the best correlation $\left(R^{2}=0.69\right)$ of the period 2001-2003 (Fig. 2). Elimination of 22 November 2001 from the correlation resulted in $R^{2}=0.82$.

\subsection{Model results}

The results for the annual net ecosystem carbon assimilation were significantly different with the different PdAM versions. The net carbon deposition with PdAM-r varied between 2.65-4.06 $\mathrm{g} \mathrm{C} \mathrm{m}^{-2} \mathrm{yr}^{-1}$ (in Table 4 given as $\mathrm{g} \mathrm{Cha}^{-1} \mathrm{yr}^{-1}$ ). The PdAM-r value for 2001-2002 was notably similar to the estimate using only mean values (see paragraph

15 3.1). PdAM- $r+s m$ and the final PdAM- $r+s m+r h$ resulted in net ecosystem carbon assimilation rates between $5.66-10.92 \mathrm{~g} \mathrm{C} \mathrm{m}^{-2} \mathrm{yr}^{-1}$ and $0.71-5.14 \mathrm{~g} \mathrm{C} \mathrm{m}^{-2} \mathrm{yr}^{-1}$, respectively. Thus, PdAM estimates roughly doubled from the model runs where only precipitation records (PdAM-r) were included to those that accounted for peak soil moisture contents $(\mathrm{PdAM}-\mathrm{r}+\mathrm{sm})$. The additional reflection of activity from condensed moisture

supply $(\mathrm{PdAM}-\mathrm{r}+\mathrm{sm}+\mathrm{rh})$ drove the annual net carbon deposition back down to the range of PdAM-r. However, the carbon flux varied $35 \%, 48 \%$ and $86 \%$ between the driest and wettest year according to PdAM-r, PdAM-r+sm and PdAM-r+sm+rh. Thus, the inter-annual variability in carbon fluxes between the years with different precipitation increased from PdAM-r to PdAM-r+sm and further to PdAM- $r+s m+r h$.
BGD

$6,7295-7324,2009$

\section{Modeling the variability in annual carbon fluxes related to BSC}

B. Wilske et al.

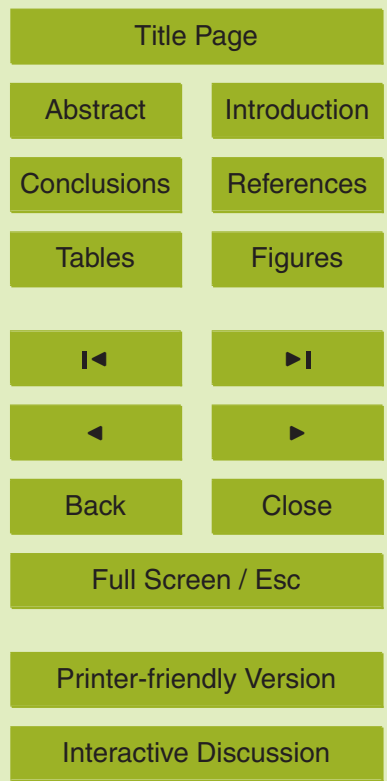




\section{Discussion}

\subsection{Model functions}

Modeling biological activity can improve the understanding of carbon dynamics, landatmosphere carbon fluxes, and related functions in ecosystems (Farquhar et al., 2001;

5 Sasai et al., 2005). To assess the BSC-related net carbon deposition at ILTER-SSK, we developed the "precipitation-driven activity model" to operate with climate data input from the adjacent TEMS station. While the fine-tuned adaptation of poikilohydric organisms to the prevalent microclimate can make carbon balance estimates difficult (Green and Lange, 1991; Ott et al., 1997), PdAM- $r+s m+r h$ successfully simulated most of the measured diurnal courses of $\mathrm{BSC}$-related $\mathrm{CO}_{2}$ fluxes. Both insufficient hydration and supra-saturation reduce $\mathrm{BSC} \mathrm{CO}_{2}$ fixation rates and limit maximal net photosynthetic rates to small windows of thallus hydration (Lange, 2001), but these aspects of BSC behaviour were reproduced well by the model. Results presented by Sundberg et al. (1997) showed that carbon gains of poikilohydric species can be fairly well assessed using microclimate-based estimates of activity periods and modeling of photosynthesis, and we have defined three important components of the organisms moisture regime that were needed to describe the activity dynamics. Deviations between measured and model data were at times negligibly small across the range of $\mathrm{CO}_{2}$ fixation rates measured, but the model also pointed out periods which did not fit well to the general flux pattern. For example, BSC-related $\mathrm{CO}_{2}$ fluxes from rewetting in November 2001 (Fig. 1a., 22/11/2001) were probably low, as it would have required longer moisture exposure to reach higher steady state photosynthesis. The same net $\mathrm{CO}_{2}$ uptake (without showing any rewetting respiration) was discussed in previous publications as being part of a "pre-activation" or gradual adaptation possibly caused by 25 several dew events after the dry season (Burgheimer et al., 2006b; Wilske et al., 2008). The model cannot simulate this type of "pre-activation" activity.

Previous studies have outlined the importance of dew for BSC growth in the Negev Desert (Veste et al., 2001; Kappen et al., 1980; Kidron et al., 2002). The parame-

\section{Modeling the variability in annual carbon fluxes related to BSC}

B. Wilske et al.

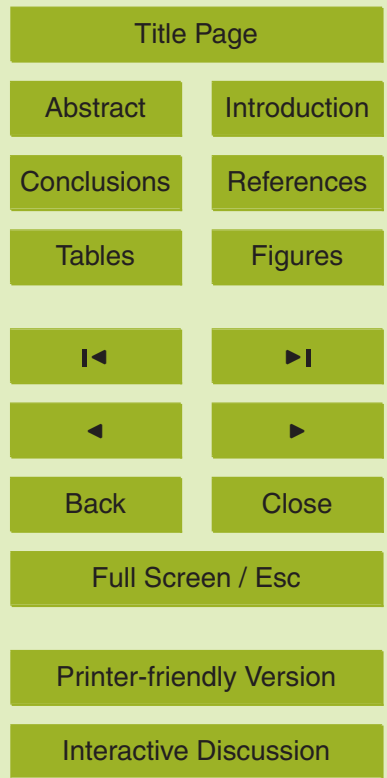


ters relative air humidity (rh) and soil moisture content (sm) were introduced to reflect moisture supply during nights from two moisture sources: (1) condensation in the form of dew from air humidity directly at the cooled down soil interface, and (2) from water or water vapour rise of accumulated rain infiltration. However, photosynthesis from in5 tense wetting by dew on the loess soil occurred much less than expected. The rh-motif in PdAM promoted mainly the night respiration, which was in accordance with our field observations. However, the rh-settings were only the best tradeoff as in some cases rh interfered negatively with other trigger components. The rh-motif also switched the algorithm to significant night respiration during the dry season. Although we have no 10 field measurements for the middle of the dry seasons, we have to consider that a part of these model emissions may be unreliable.

Lange et al. (1992) reported that the moistening of BSC by rainstorms at the Nizzana sand dune area lasted for several days. We found a similar influence of soil moisture on the activity of BSC at SSK (Wilske et al., 2008). Hence, the sm-motif is in agreement 15 with in situ observations and adds significant activity periods for BSC photosynthesis. Continuous periods of activity reduce carbon loss for mixed BSC as compared with frequent rewetting cycles that include the rewetting respiration (Lange, 2001; Lange et al., 1992). The sm-motif contributed in aligning the diurnal courses during periods of frequent precipitation events within one or two weeks. In agreement with previous results (Wilske et al., 2008), the model outputs confirm that such weeks play an important role for BSC-related carbon fluxes at ILTER-SSK.

Large differences in the annual carbon gain resulted from the different parameters that were successively incorporated into PdAM. The PdAM-r version proposed a moderate increase of carbon gain with increasing precipitation $(0.37 \mathrm{gC}$ per $\mathrm{mm}$ PPT for 25 PPT $\geq 150.8 \mathrm{~mm}$ ). Furthermore, the 2001-2002-result of PdAM-r was in agreement with the conventional method of extrapolating mean values from measured data. Nevertheless, PdAM-r was not sufficiently equipped to model several diurnal courses of measured $\mathrm{CO}_{2}$ exchange. PdAM-r+sm closed the majority of the remaining gaps particularly regarding activity during the daytime, indicating an important role of soil mois-

\section{BGD}

$6,7295-7324,2009$

\section{Modeling the variability in annual carbon fluxes related to BSC}

B. Wilske et al.

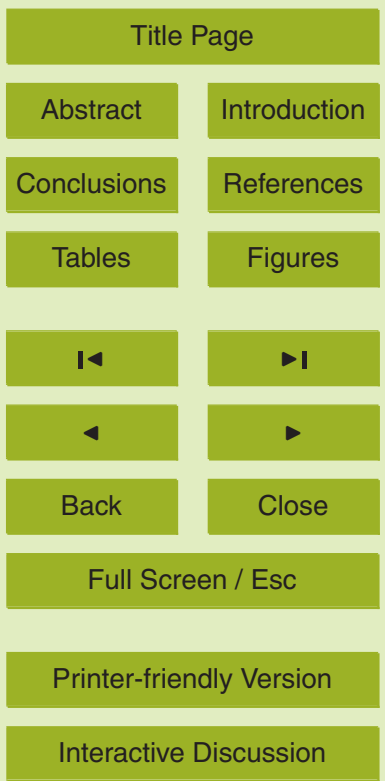


ture in the layers beneath the crust for maintaining activity. PdAM-r+sm+rh additionally activated some early morning deposition flux, but it also activated more periods of carbon loss due to dark respiration. With PdAM-r+sm and $-r+s m+r h$ larger differences in annual net carbon flux resulted from the different amounts of total annual precipitation

5 and both parameters contributed in increasing the differences. The years 2000-2003 accumulated less than the annual average of rainfall in the area. In contrast to PdAM-r, both advanced versions suggest a much stronger sensitivity of the annual carbon gain of mixed soil-dwelling BSC relative to the annual amount of PPT. With respect to the likely over-estimated emission obtained with PdAM-r+sm+rh for the dry periods of the 10 years, we assume that the model rather underestimates the BSC-related annual net carbon deposition.

\subsection{Inter-annual variability in $\mathrm{CO}_{2}$ flux}

Assessments of BSC contributions to the net carbon assimilation in ecosystems require great care, as over- or underestimations of the activity periods can result in relatively large deviations compared with the order of magnitude of the contribution (Lange et al., 1994).

Based on a total PPT of $189.1,150.8$, and $176.7 \mathrm{~mm}$ in the years (dry-to-dry season) 2000-2001, 2001-2002 and 2002-2003, the assessment resulted in 5.1, 0.7, and $2 \mathrm{~g} \mathrm{C} \mathrm{m}^{-2} \mathrm{yr}^{-1}$ for the BSC-related ecosystem net carbon deposition at ILTER-SSK, re20 spectively (Table 4). These values of carbon deposition achieved by the mixed BSC in the semiarid grass-shrubland on loess soil were lower than what has been reported for other BSC types. Lange et al. (1990) estimated the annual gross production of the fruticose soil crust lichen Teloschistes capensis in the Namib desert to be $0.41 \mathrm{~g} \mathrm{C}$ per gram carbon content of lichen thalli (biomass $40 \mathrm{~g} \mathrm{~m}^{-2}$ ). This corresponds to an annual gross 25 primary production (GPP) of $16.4 \mathrm{~g} \mathrm{C} \mathrm{m}^{-2} \mathrm{yr}^{-1}$, and to a carbon gain by the soil crust lichen of about $8 \mathrm{~g} \mathrm{C} \mathrm{m}^{-2} \mathrm{yr}^{-1}$, referring to the authors' comments that half of GPP can be accounted for by respiration. Lange et al. (1994) extrapolated from 13 days of field measurements in the coastal fog zone of the Namib desert to the average of 250 foggy

BGD

6, 7295-7324, 2009

\section{Modeling the variability in annual carbon fluxes related to BSC}

B. Wilske et al.

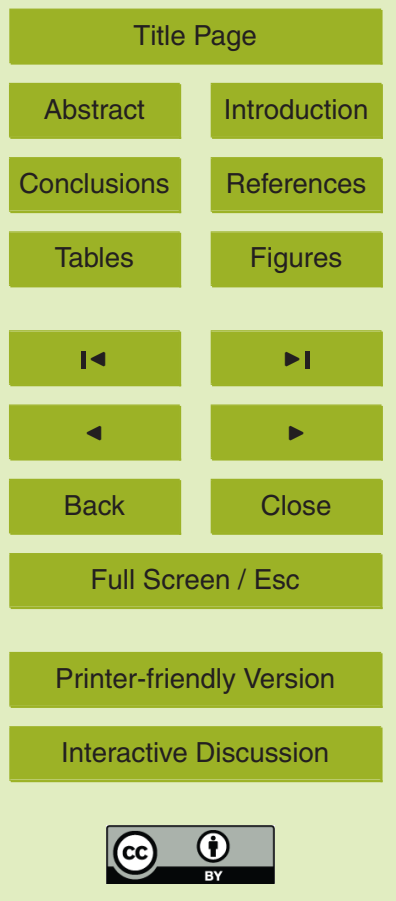


days, which resulted in a "first estimate" of the annual carbon balance of $16 \mathrm{~g} \mathrm{C} \mathrm{m}^{-2} \mathrm{yr}^{-1}$ for soil crust lichens (Acarospora cf. schleicheri, Caloplaca volkii, Lecidella crystallina). BGD Carbon gains of soil crust lichens monitored with an automatic cuvette system under temperate habitat conditions resulted in a $\mathrm{C}$ balance of 25.8 and $21.7 \mathrm{~g} \mathrm{C} \mathrm{m}^{-2} \mathrm{yr}^{-1}$ for

5 Collema cristatum and Lecanora muralis, respectively (Lange, 2000). A recent study assessed an annual net carbon gain of $14.5-21.0 \mathrm{~g} \mathrm{C} \mathrm{m}^{-2} \mathrm{yr}^{-1}$ for mats of Nostoc commune in continental Antarctica (Novis et al., 2007). With respect to the lowest carbon gain for the BSC at ILTER-SSK $\left(0.7 \mathrm{~g} \mathrm{C} \mathrm{m}^{-2} \mathrm{yr}^{-1}\right)$ one may consider, whether a sequence of years with similar low PPT $(150 \mathrm{~mm})$ would cause a significant change in 10 the species composition of the local BSC, and in turn change the BSC-related carbon deposition. However, a diverse BSC has accumulated almost $1.7 \mathrm{tha}^{-1}$ at a site in Central Karakum with an average precipitation of $148 \mathrm{~mm} \mathrm{yr}^{-1}$ (Orlovsky et al., 2004).

Assessments of the potential primary production of semiarid and arid areas range from 8.2 to $14.1 \mathrm{tha}^{-1} \mathrm{yr}^{-1}$ and from 2.0 to $7.3 \mathrm{tha}^{-1} \mathrm{yr}^{-1}$, respectively (Breckle, 15 2002). Net primary productivity (NPP) in desert scrub regions may be of the order of $70 \mathrm{~g} \mathrm{C} \mathrm{m}^{-2} \mathrm{yr}^{-1}$ (Waring and Schlesinger, 1985), although a more recent study indicated a high interannual variability in the NPP of shrub- and grasslands (Huennecke et al., 2002). In any case, such assessments probably did not reflect BSC growth. With respect to a net ecosystem deposition between 0.7 and $5.1 \mathrm{~g} \mathrm{C} \mathrm{m}^{-1} \mathrm{yr}^{-1}$, soil-dwelling 20 mixed BSC could contribute between 1 and $7 \%$ to the annual NPP of shrub-dominated drylands. The contribution to ecosystem NPP would be smaller if the areas have also grasses such as at ILTER-SSK, however, the contribution might be still in the percent range. Wohlfahrt et al. (2008) report a net ecosystem deposition of $102 \pm 67$ and $110 \pm 70 \mathrm{~g} \mathrm{C} \mathrm{m}^{-1} \mathrm{yr}^{-1}$ in a Mojave Desert ecosystem for 2005 and 2006, respectively. 25 Based on the above means, a BSC type such as in ILTER-SSK might have contributed in the order of $5 \%$ to this sink. However, PPT was $20 \%$ and $40 \%$ lower in the Mohave Desert than during the driest year at ILTER-SSK. Area index and biomass were not specified for the BSC in the Mojave Desert footprint. Hence, there is much room for speculation as to whether BSC with higher biomass and/or area index and with

\section{Modeling the variability in annual carbon fluxes related to BSC \\ B. Wilske et al.}

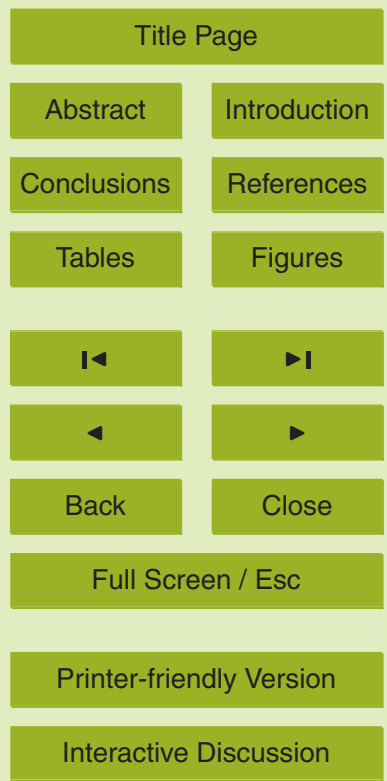


higher frequency of dew and/or fog (i.e., often unrecorded water available to BSC) may contribute significantly more to the observed carbon sink.

BGD

6, 7295-7324, 2009

\section{Conclusions}

The relatively successful simulation of measured BSC-related carbon fluxes allows two 5 major conclusions. (1) Sensitive moisture-indicating equipment should be developed and/or appropriately installed, in order to monitor BSC-relevant conditions and replace or simplify the activation switch. (2) This will allow relatively precise assessments of BSC-related carbon deposition using adapted PdAMs with minor calibrations of constants relative to specific BSC and site conditions. Overall, the observed inter-annual variability in the BSC-related carbon fluxes makes it clear that it requires more longterm research to understand the contribution of BSC to the carbon dynamics within dryland ecosystems. A potential contribution of up to $7 \%$ to the NPP of dryland ecosystems may be regarded as one of the smaller missing carbon sinks within the terrestrial biomes. However, NPP represents only a part of the ecosystem carbon budget. To derive a more comprehensive metric, such as net biome exchange, would require information on the fate of BSC carbon, which is not available at this time.

\section{Appendix A}

\section{The algorithm}

20 PdAM includes an algorithm in the form published by Schuh et al. (1997). The algorithm was modified to model the photosynthetic and respiratory activity of BSC (see Eq. A1). The constants were fitted to reflect BSC photosynthesis and respiration as measured in situ. The variables $(L, T)$ were derived from meteorological records. BSC activity is switched on by means of $Z$ representing the triggered activation switch (i.e., depending

\section{Modeling the variability in annual carbon fluxes related to BSC}

B. Wilske et al.

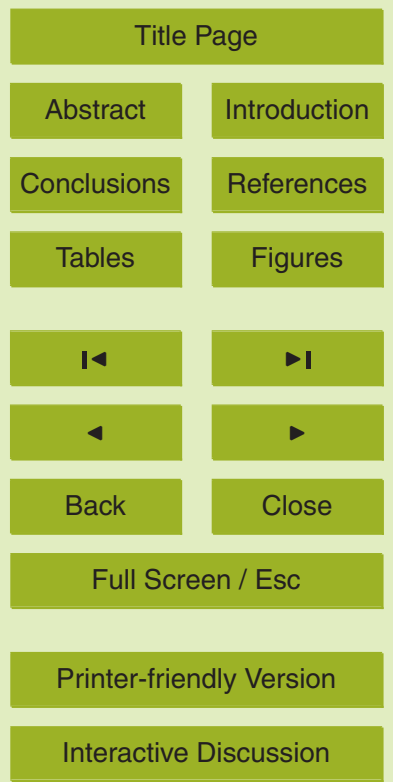


on moisture availability: $0.25,0.375,0.5,0.75$ or 1.0$)$. In case of no activation $Z=0$.

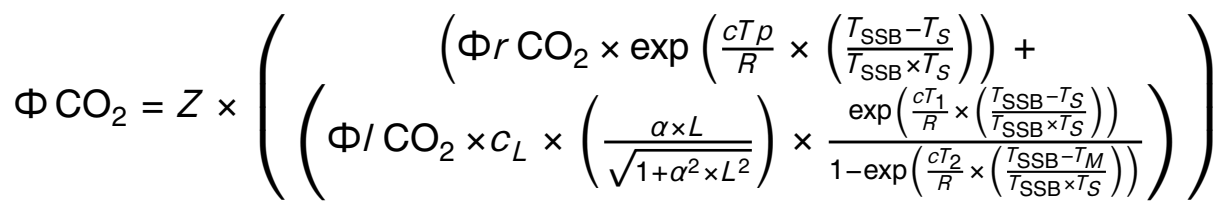

where $\Phi_{\mathrm{CO}_{2}}\left(\mu \mathrm{molm}{ }^{-2} \mathrm{~s}^{-1}\right)$ is the BSC-related net $\mathrm{CO}_{2}$ flux, $\Phi_{\mathrm{CO}_{2}}=0.30$ $\left(\mu \mathrm{mol} \mathrm{m}{ }^{-2} \mathrm{~s}^{-1}\right)$ is the base emission due to respiration, $\Phi \mathrm{I}_{\mathrm{CO}_{2}}=-4\left(\mu \mathrm{mol} \mathrm{m}{ }^{-2} \mathrm{~s}^{-1}\right)$ is 5 the base deposition due to net photosynthesis including compensation for concurrent respiration, $T_{\mathrm{SSB}}\left({ }^{\circ} \mathrm{C}\right.$ ) is the $\mathrm{BSC}$-affecting temperature (see 3.2 .3 ), $T_{S}=20^{\circ} \mathrm{C}$ is a fitted base temperature for the temperature relations of both photosynthesis and respiration (originally: the standard temperature for VOC emissions), $L$ is solar insulation $\left(\mathrm{W} \mathrm{m}^{-2}\right.$ ) (originally: photosynthetic active radiation), $R=8.314\left(\mathrm{~J} \mathrm{~K}^{-1} \mathrm{~mol}^{-1}\right)$ is the gas constant, 10 and $\alpha=0.003829, c T_{P}=130, C_{L}=1.1974, c T_{1}=30, c T_{2}=9$, and $T_{M}=10$ are empirical constants to modulate photosynthesis and respiration.

Acknowledgements. This study was supported by a fellowship of the Minerva Society to B. W. We also gratefully acknowledge the financial support by the Max Planck Society. We are much obliged to the Mitrani Department of Desert Ecology, Ben-Gurion University of the Negev,

15 Sede Boqer Campus, for providing the base for the fieldwork. We are grateful to T. Andreae for the English corrections.

The service charges for this open access publication have been covered by the Max Planck Society.

\section{References}

Belnap, J.: The potential roles of biological soil crusts in dryland hydrological cycles, Hydrol. Process., 20, 3159-3178, 2006.

Belnap, J. and Gillette, D. A.: Disturbance of biological soil crusts: impacts on potential wind erodibility of sandy desert soils in southeastern Utah, Land Degrad. Dev., 8, 355-362, 1997.

\section{BGD}

$6,7295-7324,2009$

\section{Modeling the variability in annual carbon fluxes related to BSC}

B. Wilske et al.

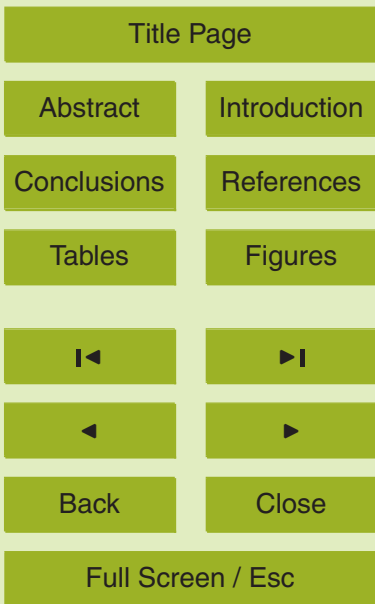

Printer-friendly Version

Interactive Discussion 
Belnap, J. and Lange, O. L. (Eds.): Biological Soil Crusts: Structure, Function and Management, Springer, Heidelberg-Berlin, 503 pp., 2001.

Belnap, J., Buedel, B., and Lange, O. L.: Biological Soil Crusts: Characteristics and Distribution, in: Biological Soil Crusts: Structure, Function, and Management, edited by: Belnap, J. and

$5 \quad$ Lange, O. L., Springer, Heidelberg-Berlin, 3-30, 2001.

Beymar, R. J. and Klopatek, J. M.: Potential contribution of carbon by Microphytic Crusts in Pinyon-Juniper Woodlands, Arid Soil Res. Rehab., 5(2), 187-198, 1991.

Boeken, B., Ariza, C., Gutterman, Y., and Zaady, E.: Environmental factors affecting dispersal, germination and distribution of Stipa capensis in the Negev Desert, Israel, Ecol. Res., 19, $10 \quad 533-540,2004$.

Breckle, S.-W.: Walter's vegetation of the earth, The ecological systems of the geo-biosphere, 4th edn., Springer, Berlin, 527 pp., 2002.

Burgheimer, J., Wilske, B., Maseyk, K., Karnieli, A., Zaady, E., Yakir, D., and Kesselmeier, J.: Ground and space spectral measurements for assessing semi-arid ecosystem phenology related to $\mathrm{CO}_{2}$ fluxes of biological soil crusts, Rem. Sens. Environ., 101, 1-12, 2006a.

Burgheimer, J., Wilske, B., Maseyk, K., Karnieli, A., Zaady, E., Yakir, D., and Kesselmeier, J.: Relationships between Normalized Difference Vegetation Index (NDVI) and carbon fluxes of biological soil crusts assessed by ground measurements, J. Arid Environ., 64, 651-669, 2006b.

Dolman, A. J., Schulze, E. D., and Valentini, R.: Analyzing carbon flux measurements, Science, 301, p. 916, 2003.

Elbert, W., Weber, B., Büdel, B., Andreae, M. O., and Pöschl, U.: Microbiotic crusts on soil, rock and plants: neglected major players in the global cycles of carbon and nitrogen?, Biogeosciences Discuss., 6, 6983-7015, 2009, http://www.biogeosciences-discuss.net/6/6983/2009/.

Evans, R. D. and Johansen, J. R.: Microbiotic crusts and ecosystem processes, Crit. Rev. Plant Sci., 18(2), 183-225, 1999.

Evans, R. D. and Lange, O. L.: Biological Soil Crusts and ecosystem nitrogen and carbon dynamics, in: Biological Soil Crusts: Structure, Function, and Management, edited by: Belnap,

30 J. and Lange, O. L., Springer, Heidelberg-Berlin, 263-280, 2001.

Farquhar, G. D., von Caemmerer, S., and Berry, J. A.: Models of Photosynthesis, Plant Physiol., 125, 42-45, 2001.

Friedmann, E. I. and Galun, M.: Desert algae, lichens and fungi, in: Desert Biology, edited by:

\section{BGD}

6, 7295-7324, 2009

\section{Modeling the variability in annual \\ carbon fluxes related to BSC}

B. Wilske et al.

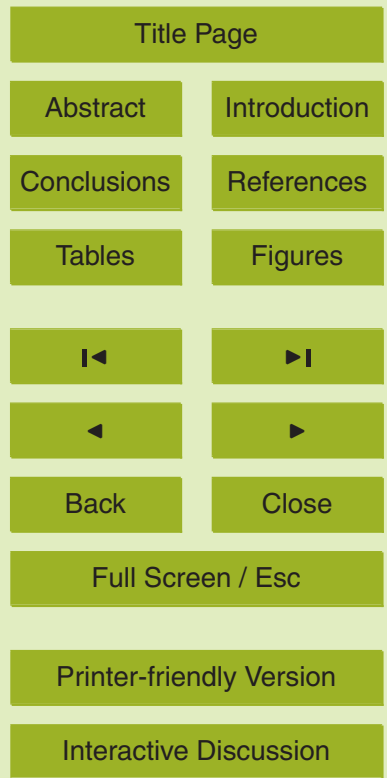


Brown, G. W., Academic Press, London, 2, 165-212, 1974.

Gosz, J. R., French, C., and Sprott, P.: The International Long Term Ecological Research Network, University of New Mexico, Albuquerque, NM, 109 pp., 2000.

Green, T. G. A. and Lange, O. L.: Ecophysiological Adaptations of the Lichen Genera Pseudocyphellaria and Sticta to South Temperate Rainforests, Lichenologist, 23, 267-282, 1991.

Guenther, A. B., Zimmerman, P. R., Harley, P. C., Monson, R. K., and Fall, R.: Isoprene and Monoterpene Emission Rate Variability - Model Evaluations and Sensitivity Analyses, J. Geophys. Res.-Atmos., 98, 12609-12617, 1993.

Guenther, A.: Seasonal and spatial variations in natural volatile organic compound emissions, 10 Ecol. Appl., 7, 34-45, 1997.

Guo, Y., Zhao, H., Zuo, X., Drake, S., and Zhao, X.: Biological soil crust development and its topsoil properties in the process of dune stabilization, Inner Mongolia, China, Environ. Geol., 54, 653-662, 2008.

Housman, D. C., Powers, H. H., Collins, A. D., and Belnap, J.: Carbon and nitrogen fixation 15 differ between successional stages of biological soil crusts in the Colorado Plateau and Chihuahuan Desert, J. Arid Environ., 66, 620-634, 2006.

Huenneke, L. F., Anderson, J. P., Remmenga, M., and Schlesinger, W. H.: Desertification alters patterns of aboveground net primary production in Chihuahuan ecosystems, Glob. Change Biol., 8, 247-264, 2002.

20

IPCC (Intergovernmental Panel on Climate Change): The carbon cycle and atmospheric carbon dioxide, in: Climate Change 2001: The Scientific Basis, Contribution of Working Group I to the Third Assessment Report of the Intergovernmental Panel on Climate Change, edited by: Houghton, J. T., Ding, Y., Griggs, D. J., Noguer, M., van der Linden, P. J., Dai, X., Maskell, K., and Johnson, C. A., Cambridge University Press, Cambridge, 183-237, 2001.

Jeffries, D. L., Link, S. O., and Klopatek, J. M.: $\mathrm{CO}_{2}$ fluxes of cryptogamic crusts. I. Response to resaturation, New Phytol., 125, 163-173, 1993a.

Jeffries, D. L., Link, S. O., and Klopatek, J. M.: $\mathrm{CO}_{2}$ fluxes of cryptogamic crusts. II. Response to rehydration, New Phytol., 125, 391-396, 1993b.

Kappen, L., Lange, O. L., Schulze, E.-D., Buschbom, U., and Evenari, M.: Ecophysiological investigations on lichens of the Negev Desert. VII. The influence of habitat exposure on dew imbibition and photosynthetic productivity, Flora, 169, 216-229, 1980.

Karnieli, A., Kokaly, R. F., West, N. E., and Clark, R. N.: Remote sensing of biological soil crusts, in: Biological Soil Crusts: Structure, Function, and Management, edited by: Belnap,
BGD

$6,7295-7324,2009$

\section{Modeling the variability in annual \\ carbon fluxes related to BSC}

B. Wilske et al.

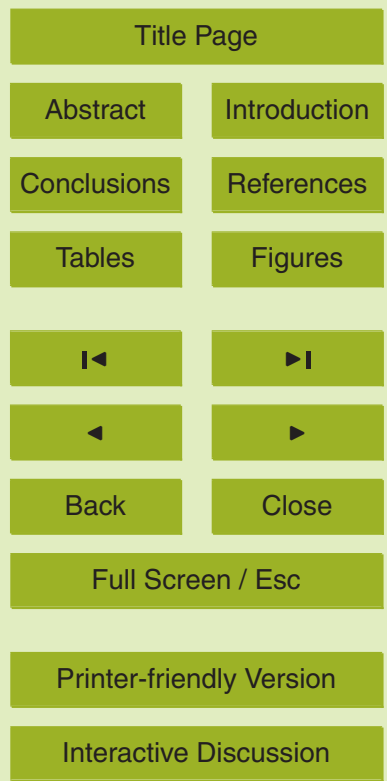


J. and Lange, O. L., Springer, Heidelberg-Berlin, 431-455, 2001.

Karnieli, A., Shachak, M., and Tsoar, H.: The effect of microphytes on the spectral reflectance of vegetation in semiarid regions, Remote Sens. Environ., 57, 88-96, 1996.

Karnieli, A. and Tsoar, $\mathrm{H}$.: Spectral reflectance of biogenic crust developed on desert dune sand along the Israel-Egypt border, Int. J. Remote Sens., 16, 369-374, 1995.

Kesselmeier, J., Ciccioli, P., Kuhn, U., Stefani, P., Biesenthal, T., Rottenberger, S., Wolf, A., Vitullo, M., Valentini, R., Nobre, A., Kabat, P., and Andreae, M. O.: Volatile organic compound emissions in relation to plant carbon fixation and the terrestrial carbon budget, Global Biogeochem. Cy., 16, 1126-1134, 2002.

10 Kidron, J. G., Herrnstadt, I., and Barzilay, E.: The role of dew as a moisture source for sand microbiotic crusts in the Negev Desert, Israel, J. Arid Environ., 52, 517-533, 2002.

Lange, O. L.: Photosynthesis of soil-crust biota as dependent on environmental factors, in: Biological Soil Crusts: Structure, Function, and Management, edited by: Belnap, J. and Lange, O. L., Springer, Heidelberg-Berlin, 217-241, 2001.

Lange, O. L.: Photosynthetic performance of a gelatinous lichen under temperate habitat conditions: long-term monitoring of $\mathrm{CO}_{2}$ exchange of Collema cristatum, Bibl. Lichenologica, 75, 307-332, 2000.

Lange, O. L., Belnap, J., and Reichenberger, H.: Photosynthesis of the cyanobacterial soilcrust lichen Collema tenax from arid lands in southern Utah, USA: role of water content on light and temperature responses of $\mathrm{CO}_{2}$ exchange, Funct. Ecol., 12, 195-202, 1998.

Lange, O. L., Reichenberger, $\mathrm{H}$., and Walz, $\mathrm{H}$.: Continuous monitoring of $\mathrm{CO}_{2}$ exchange of lichens in the field: short-term enclosure with an automatically operating cuvette, Lichenologist, 29, 259-274, 1997.

Lange, O. L., Meyer, A., Zellner, H., and Heber, U.: Photosynthesis and water relations of lichen soil crusts: field measurements in the coastal fog zone of the Namib Desert, Funct. Ecol., 8, 253-264, 1994.

Lange, O. L., Kidron, G. J., Büdel, B., Meyer, A., Kilian, E., and Abeliovich, A.: Taxonomic composition and photosynthetic characteristics of the "biological soil crusts" covering the sand dunes in the western Negev Desert, Funct. Ecol., 6, 519-527, 1992.

30 Lange, O. L., Meyer, A., Zellner, H., Ullmann, I., and Wessels, D. C. J.: Eight days in the life of a desert lichen: water relations and photosynthesis of Teloschistes capensis in the coastal fog zone of the Namib Desert, Madoqua, 17, 17-30, 1990.

Lange, O. L., Schulze, E.-D., and Koch, W.: Ecophysiological investigations on lichens of the
BGD

$6,7295-7324,2009$

\section{Modeling the variability in annual \\ carbon fluxes related to BSC}

B. Wilske et al.

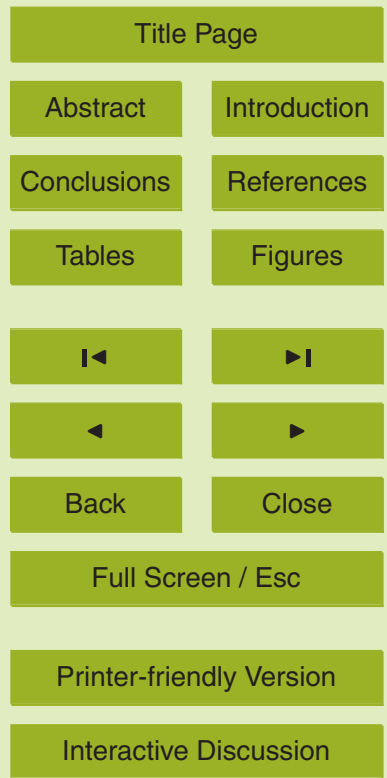


Negev Desert. III. $\mathrm{CO}_{2}$ gas exchange and water relations of crustose and foliose lichens in their natural habitat during the summer dry period, Flora, 159, 525-528, 1970.

Lázaro, R., Cantón, Y., Solé-Benet, A., Bevan, J., Alexander, R., Sancho, L. G., and Puigdefábregas, J.: The influence of competition between lichen colonization and erosion 5 on the evolution of soil surfaces in the Tabernas badlands (SE Spain) and its landscape effects, Geomorphology, 102, 252-266, 2008.

Novis, P. M., Whitehead, D., Gregorich, E. G., Hunt, J. E., Sparrow, A. D., Hopkins, D. W., Elberling, B., and Greenfield, L. G.: Annual carbon fixation in terrestrial populations of Nostoc commune (Cyanobacteria) from an Antarctic dry valley is driven by temperature regime,

10 Glob. Change Biol., 13, 1224-1237, 2007.

Orlovsky, L., Dourikov, M., and Babaev, A.: Temporal dynamics and productivity of biogenic soil crusts in the central Karakum desert, Turkmenistan, J. Arid Environ., 56, 579-601, 2004.

Ott, S., Elders, U., and Jahns, H. M.: Vegetation of the rock-alvar of Gotland II. Microclimate of lichen-rich habitats, Nova Hedwigia, 64, 87-101, 1997.

15 Palmer Jr., R. J. and Friedmann, E. I.: Water relations, thallus structure and photosynthesis in Negev desert lichens, New Phytol., 116, 597-603, 1990.

Rosentreter, R., Bowker, M., and Belnap, J.: A Field Guide to Biological Soil Crusts of Western US Drylands, US Government Printing Office, Denver, 103 pp., 2007.

Sasai, T., Ichii, K., Yamaguchi, Y., and Nemani, R.: Simulating terrestrial carbon fluxes using the new biosphere model "biosphere model integrating eco-physiological and mechanistic approaches using satellite data" (BEAMS), J. Geophys. Res., 110, G02014, doi:10.1029/2005JG000045, 2005.

Schuh, G., Heiden, A. C., Hoffmann, T., Kahl, J., Rockel, P., Rudolph, J., and Wildt, J.: Emissions of volatile organic compounds from sunflower and beech: dependence on temperature and light intensity, J. Atmos. Chem., 27, 291-318, 1997.

Sharpe, P. J. H. and Demichele, D. W.: Reaction Kinetics of Poikilotherm Development, J. Theor. Biol., 64, 649-670, 1977.

Stone, R.: Have desert researchers discovered a hidden loop in the carbon cycle?, Science, 320, 1409-1410, 2008.

30 Sundberg, B., Palmqvist, K., Esseen, P.-A., and Renhorn, K.-E.: Growth and vitality of epiphytic lichens, II. Modelling of carbon gain using field and laboratory data, Oecologia, 109, 10-18, 1997.

UNEP (United Nations Environment Program): World Atlas of Desertification, 2nd edn., Arnold

BGD

6, 7295-7324, 2009

\section{Modeling the variability in annual \\ carbon fluxes related to BSC}

B. Wilske et al.

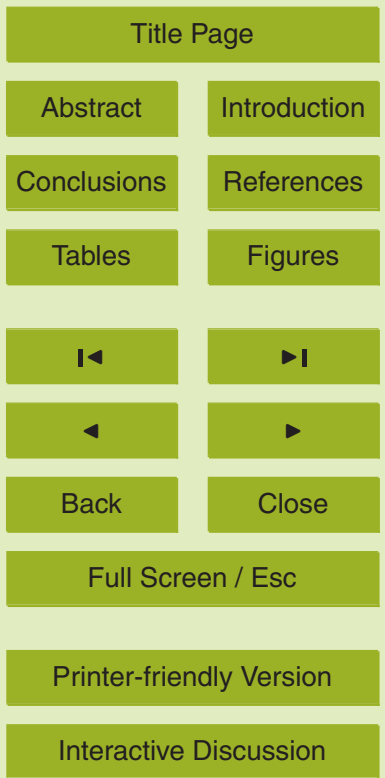


Publisher, London, 182 pp., 1997.

Veste, M., Littmann, T., and Friedrich, H.: Microclimate boundary conditions for activity of soil lichen crusts in sand dunes of the north-western Negev desert, Israel, Flora, 196, 465-474, 2001.

5 Waring, R. H. and Schlesinger, W. H.: Forest ecosystems: concepts and management, Academic Press, Orlando, 340 pp., 1985.

West, N. E.: Structure and function of microphytic soil crust in wildland ecosystems of arid and semiarid regions, Advance. Ecol. Res., 20, 179-223, 1990.

Whittaker, R. H. and Likens, G. E.: The biosphere and man, in: Primary Productivity of the Biosphere, edited by: Lieth, H. and Whittaker, R. H., Springer, New York, 306-328, 1975.

Wilske, B., Burgheimer, J., Karnieli, A., Zaady, E., Andreae, M. O., Yakir, D., and Kesselmeier, J.: The $\mathrm{CO}_{2}$ exchange of biological soil crusts in a semiarid grass-shrubland at the northern transition zone of the Negev desert, Israel, Biogeosciences, 5, 1411-1423, 2008, http://www.biogeosciences.net/5/1411/2008/.

15 Wohlfahrt, G., Fenstermaker, L. F., and Arnone, J. A.: Large annual net ecosystem $\mathrm{CO}_{2}$ uptake of a Mojave Desert ecosystem, Glob. Change Biol., 14, 1475-1487, 2008.

Xie, J., Li, Y., Zhai, C., Li, C., and Lan, Z.: $\mathrm{CO}_{2}$ absorption by alkaline soils and its implication to the global carbon cycle, Environ. Geol., 56, 953-961, doi:10.1007/s00254-008-1197-0, 2008.

20

Zaady, E., Groffman, P., and Shachak, M.: Nitrogen fixation in macro- and microphytic patches in the Negev desert, Soil Biol. Biochem., 30, 449-454, 1998.

Zaady, E., Kuhn, U., Wilske, B., Sandoval-Soto, L., and Kesselmeier, J.: Patterns of $\mathrm{CO}_{2}$ exchange in biological soil crusts of successional age, Soil Biol. Biochem., 32, 959-966, 2000.

Zhang, Z. S., Liu, L. C., Li, X. R., Zhang, J. G., He, M. Z., and Tan, H. J.: Evaporation properties 2008.

\section{BGD}

$6,7295-7324,2009$

\section{Modeling the variability in annual \\ carbon fluxes related to BSC}

B. Wilske et al.

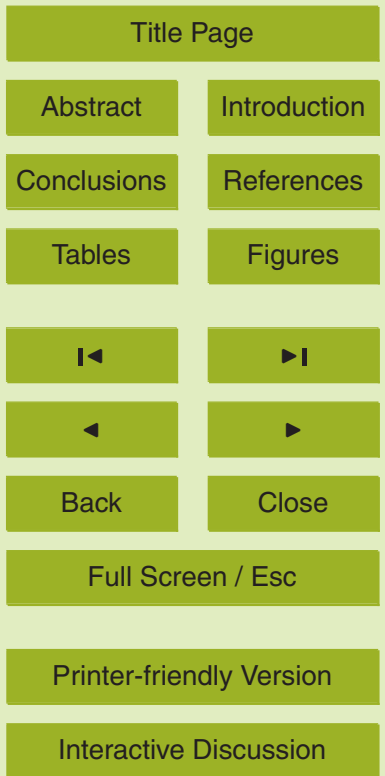




\section{BGD}

6, 7295-7324, 2009

\section{Modeling the variability in annual carbon fluxes related to BSC \\ B. Wilske et al.}

Table 1. Empirical setting of switches to drive the algorithm for BSC activity. Model settings for the periods of BSC activity represent a compromise between observed highly variable length of periods during days $\left(^{*}\right)$ and the maximum length during nights $\left(^{* *}\right)$.

\begin{tabular}{llllc}
\hline Driving moisture & \multicolumn{4}{c}{$\begin{array}{c}\text { Duration of activity in hours and minutes (hh:mm) } \\
\text { model settings switch observed length day }{ }^{\star} / / \mathrm{night}^{\star *}\end{array}$} \\
\hline precipitation $(\mathrm{mm})$ & 0.1 & $02: 00$ & $\mathrm{I} 1$ & $00: 15-01: 00 / / 04: 00$ \\
& 0.5 & $03: 00$ & 12 & $01: 00-03: 00 / / 08: 00$ \\
& 1.0 & $08: 00$ & 13 & $01: 00-05: 00 / / 12: 00$ \\
& 2.0 & $11: 30$ & 14 & $01: 00-08: 00 / / 12: 00$ \\
& 3.0 & $15: 00$ & 15 & $02: 00-12: 00 / / 12: 00$ \\
& 5.0 & $24: 00$ & 16 & $>12: 00 / />12: 00$ \\
soil moisture $\left(\mathrm{cm}^{3} \mathrm{~cm}^{-3}\right)$ & $>0.22$ & $00: 15$ & 17 & \\
relative air humidity $(\%)$ & $>83.2$ & $00: 15$ & 18 & \\
\hline
\end{tabular}

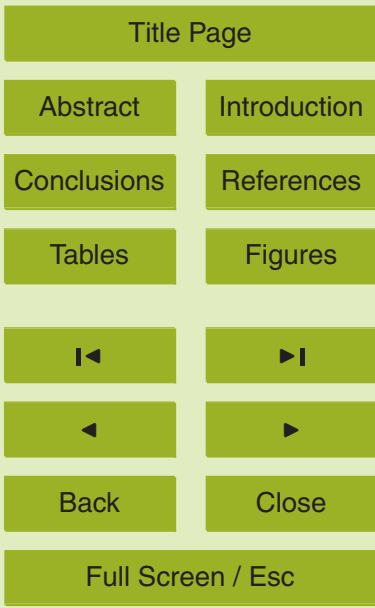

Printer-friendly Version

Interactive Discussion 
Table 2. Moisture characteristics of the periods used for model development (in chronological order following Fig. 1).

\begin{tabular}{ll}
\hline Date/month/year & Moisture characteristics \\
\hline $21-23 / 11 / 2001$ & $\begin{array}{l}\text { Moderate rain events at the onset of the winter rain season. Less than } \\
10 \text { mm PPT fell within the previous three weeks. }\end{array}$ \\
$16-18 / 12 / 2001$ & $\begin{array}{l}\text { Partially moist BSC surfaces from water drops, which condensed on dry } \\
\text { but standing grass blades and dropped wetting surrounding surfaces. } \\
\text { Recurring PPT alternating between rainstorm and drizzle. Rates of BSC } \\
\text { photosynthesis indicating at least temporary water supra-saturation. } \\
\text { Water condensation on soil surfaces during nights. Intensity of surface }\end{array}$ \\
$13-15 / 01 / 2002$ & $\begin{array}{l}\text { moisture and VWC of the upper soil column pointing to a recycling of } \\
\text { water from recent infiltration (14 and 15 January). }\end{array}$ \\
$19-21 / 01 / 2002$ & $\begin{array}{l}\text { Fog in the morning of 20/01, subsequent rain and frequent changes of } \\
\text { cloudy and sunny conditions with maximum photosynthesis (21/01). } \\
\text { Low moisture supply from raindrops (<0.5 mm, 23/11 15:30) and shower } \\
\text { (<1 mm around midnight 24-25/11). }\end{array}$ \\
$10-12 / 12 / 2002$ & $\begin{array}{l}\text { Supra-saturation of BSC due to continuous rain (11/12) and reduction of } \\
\text { BSC activity due to cloudy weather and wind drying the following day. } \\
\text { Repeated rain showers alternating with cloud-free light conditions result- } \\
\text { ing in maximum photosynthesis rates. }\end{array}$ \\
$19-21 / 01 / 2003$ & $\begin{array}{l}\text { Effective wind drying with higher wind speeds after 22/02 09:00 until the } \\
\text { next precipitation. } \\
\text { Hot and dry days with lowest moisture supply from condensation during } \\
\text { the nights evaporating with early morning sunlight. }\end{array}$ \\
$20-24 / 02 / 2003 / 2002 / 2003$ &
\end{tabular}

\section{Modeling the variability in annual carbon fluxes related to BSC}

B. Wilske et al.

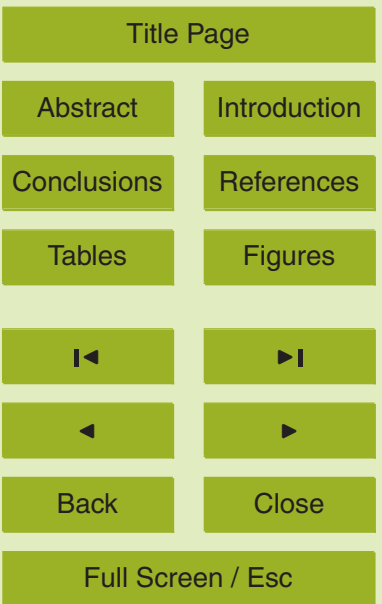

Printer-friendly Version

Interactive Discussion 


\section{BGD}

6, 7295-7324, 2009

Table 3. Scheme of the switch and trigger modules of the precipitation-driven activity model with their output being a factor $Z$ to switch the algorithm on/off.

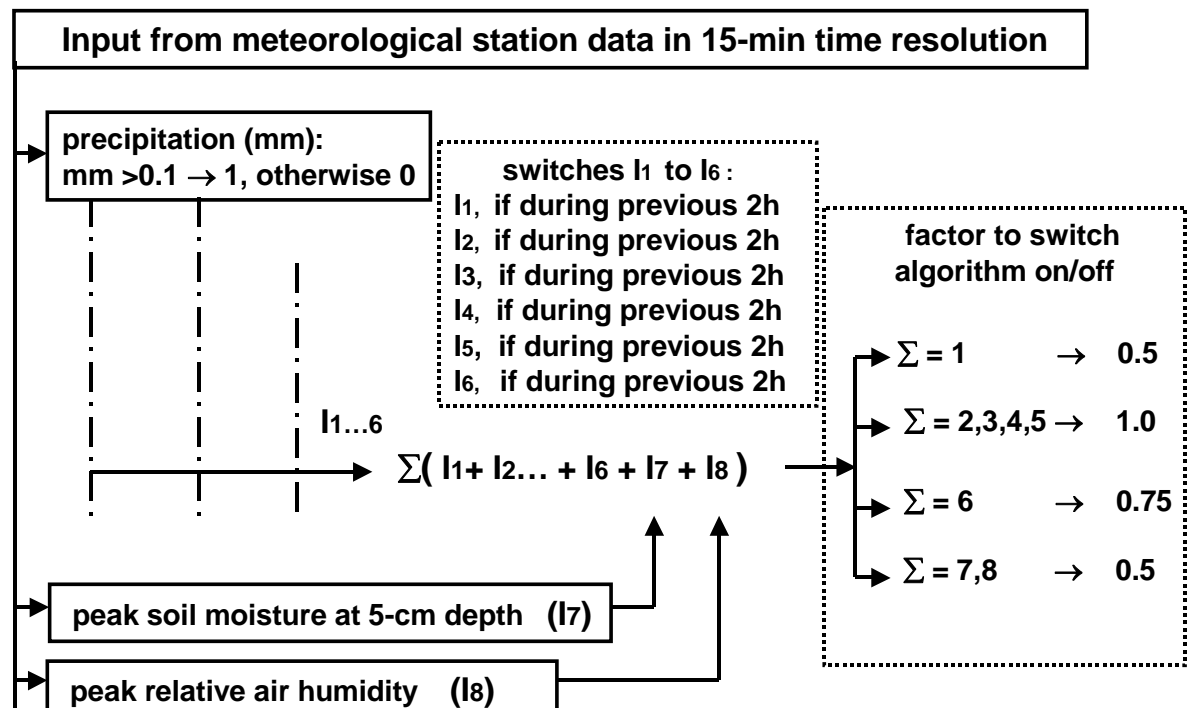

Modeling the variability in annual carbon fluxes related to BSC

B. Wilske et al.

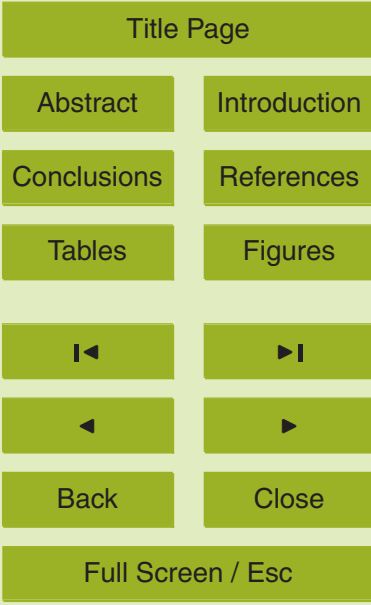

Printer-friendly Version

Interactive Discussion 


\section{BGD}

6, 7295-7324, 2009

\section{Modeling the variability in annual \\ carbon fluxes related to BSC}

Table 4. Inter-annual variability in BSC-related net carbon deposition as assessed by the precipitation-driven activity model (PdAM). BSC area index for calculations was 0.6. Modifications in the model reflect water supply from (a) rain " $r$ ", (b) rain and increased soil moisture " $\mathrm{r}+\mathrm{sm}$ ", and (c) rain, soil moisture, and high relative air humidity " $r+s m+r h "$. Years were calculated from 1 July to 30 June the following year with the peak activity around the turn of the years (winter rain climate).

\begin{tabular}{lclrr}
\hline Yr period & PPT $(\mathrm{mm})$ & \multicolumn{3}{l}{ BSC-related carbon deposition, C $\left(\mathrm{kg} \mathrm{ha}^{-1} \mathrm{yr}^{-1}\right)$} \\
& & (a) “r” & (b) “r+sm” & (c) " $\mathrm{r}+\mathrm{sm}+\mathrm{rh}$ " \\
\hline $2002-2003$ & 176.7 & 34.7 & 66.8 & 20.4 \\
$2001-2002$ & 150.8 & $26.5\left(27^{*}\right)$ & 56.6 & 7.1 \\
$2000-2001^{* *}$ & 189.1 & 40.6 & 109.2 & 51.4 \\
\hline
\end{tabular}

B. Wilske et al.

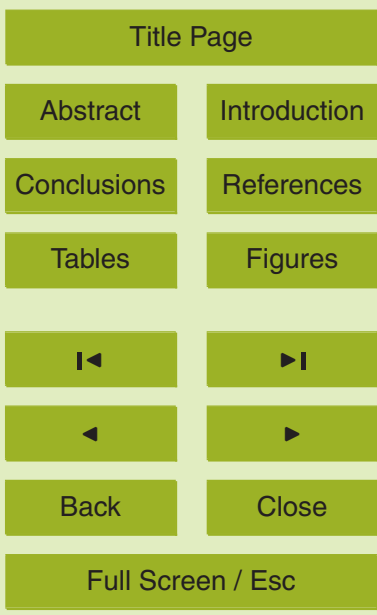

* as assessed from measured mean values, see paragraph 3.1;

${ }^{* *}$ note that no field experiments were conducted before the season 2001-2002. 

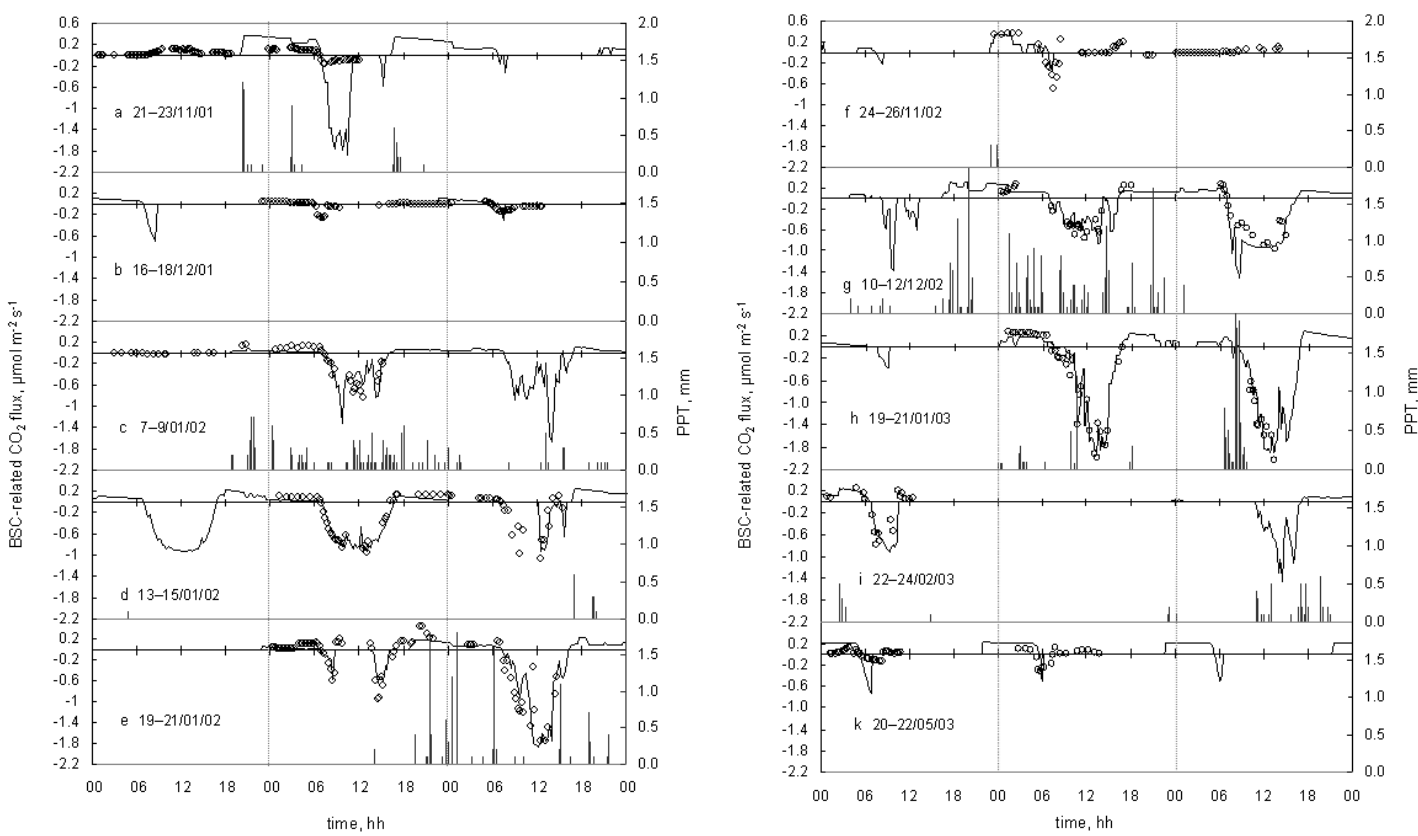

6, 7295-7324, 2009

\section{Modeling the variability in annual carbon fluxes related to BSC}

B. Wilske et al.

Fig. 1. Ten 3-day runs of PdAM-r+sm+rh and the measured BSC-related net $\mathrm{CO}_{2}$ flux of $B S C$, representing a range of moisture regimes and sources in the BSC environment. Left $y$-axis: modelled (solid line) and measured (circles) values of the 15-min mean $\mathrm{CO}_{2}$ flux $\left(\mu \mathrm{mol} \mathrm{m} \mathrm{m}^{-2} \mathrm{~s}^{-1}\right)$; uptake negative, emission positive. Right $\mathrm{y}$-axis: precipitation ( $\left.\mathrm{mm} \mathrm{15}-\mathrm{min}^{-1}\right)$ (vertical bars). X-axis: time (hour, GMT + 02:00) of three consecutive days.

Title Page

Abstract

Introduction

Conclusions

References

Tables

Figures

14

4

Back

Close

\section{Full Screen / Esc}

Printer-friendly Version

Interactive Discussion 
BGD

2001-2003

$-2.5$

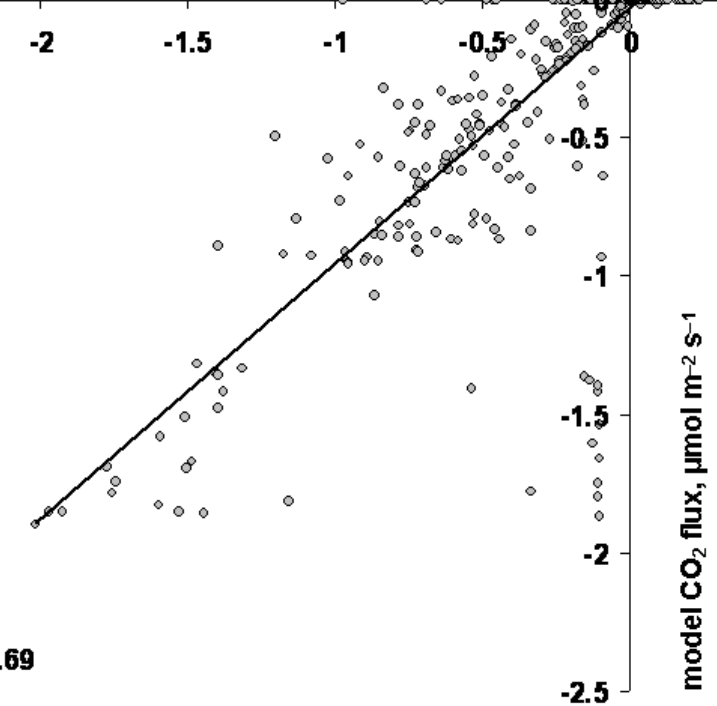

$\mathbf{0 . 5}$

$$
R^{2}=0.69
$$

Fig. 2. Correlation between BSC-related 15-min mean of net $\mathrm{CO}_{2}$ fluxes $\left(\mu \mathrm{mol} \mathrm{m}{ }^{-2} \mathrm{~s}^{-1}\right)$ from insitu measurements ( $\mathrm{x}$-axis) and PdAM- $r+s m+r h$, incorporating PPT, high $\mathrm{RH}$ and peak VWC for activity, and high wind speed for drying (y-axis). High model- versus low measured flux indicates that the model drying process was not effective during some days.
6, 7295-7324, 2009

Modeling the variability in annual carbon fluxes related to BSC

B. Wilske et al.

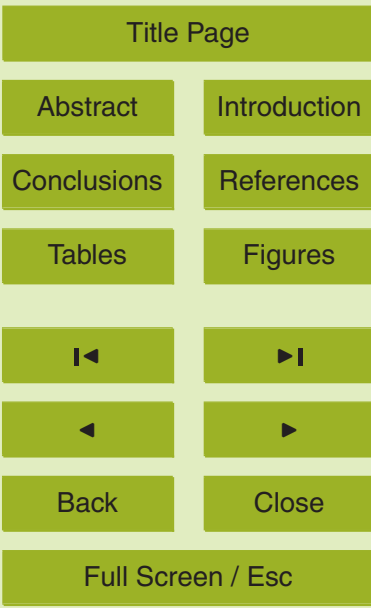

Printer-friendly Version

Interactive Discussion 